\title{
The Cost of Growing Old: Business Necessity and the Age Discrimination in
}

Employment Act

In passing the Age Discrimination in Employment Act (ADEA), 1 Congress resolved to promote and protect the rights of older workers, including their right not to be discharged on the basis of age. ${ }^{2}$ Securing this right may require employer expenditures, just as employers have elsewhere been forced to bear additional costs in order to further the remedial objectives of federal employment discrimination legislation. ${ }^{3}$ Yet the ADEA was not intended to impose crippling cost burdens on employers, and they retain the opportunity to make prudent business decisions based on cost considerations. ${ }^{4}$

The tension between an older employee's right to be evaluated without regard to his age and an employer's discretion to respond to business exigencies is reflected in an increased focus on the problem of illegal employee terminations under the ADEA. ${ }^{5}$ Employers faced with

1. 29 U.S.C. $\$ \S 621-634$ (1970 \& Supp. V 1975), as amended by Pub. L. No. 95-256, $\$ \S 1-7,92$ Stat. 189 (1978) [hereinafter cited as ADEA].

2. See ADEA, $\$ 2,29$ U.S.C. $\$ 621$ (1970) (statement of findings and purpose); id. $\S 4(\mathrm{a})(1), 29$ U.S.C. $\$ 623(\mathrm{a})(1)$ (1970) (illegal to discharge because of age). Originally the Act protected employees or applicants between the ages of 40 and 65. See Pub. L. No. 90-202, $\$ 12,81$ Stat. 607 (1967). Congress subsequently expanded the general protection of the Act to include individuals from ages 40 to 70, and abolished totally the maximum protected age for federal government employees. Age Discrimination in Employment Act Amendments of 1978, Pub. L. No. 95-256, $\S \S 3(\mathrm{a}), 5(\mathrm{a}), 92$ Stat. 189 (to be codified in 29 U.S.C. $\$ \S 631,633 a)$.

3. See, e.g., Albemarle Paper Co. v. Moody, 422 U.S. 405, 431-36 (1975) (by implication requiring employer to bear cost of validating pre-employment tests under Title VII of 1964 Civil Rights Act, 42 U.S.C. $\$ \$ 2000$ e to 2000e-17 (1970 \& Supp. V 1975)); United States v. Sheet Metal Workers Local 36, 416 F.2d 123, 139-40 (8th Cir. 1969) (by implication requiring employer to bear cost of publicizing job opportunities under Title VII). In the course of its analysis of the ADEA, this Note draws on judicial interpretations of comparable provisions and purposes of Title VII. There are important similarities between the two statutes, but also significant differences. See notes 20, 26, 34 \& 59 infra; Lorillard v. Pons, 434 U.S. 575, $584-85$ (1978).

4. See note 90 infra (employer's right to offer lesser pension, retirement, or insurance benefits to newly hired older workers). Ultimately, of course, ADEA protection is of no value to older employees if the employer cannot maintain his business.

5. The number of identified illegal discharges has risen steadily from 181 in 1973 to 500 in 1976. Over the same period, the number of refusals to hire has declined from 957 to 552. See U.S. Employment Standards Administration, Dep't of Labor, Age Discrimination in Employment Act of 1967: A Report Covering Activities Under the Act Durinc 1976, at 3 (1977) [hereinafter cited as 1976 ADEA ANNUAL REPORT]; U.S. EMPLOYMENT 
adverse business conditions may initiate as an austerity measure personnel reductions that have a disparate impact ${ }^{\mathfrak{b}}$ on older employees. Such cost-based reductions arguably conflict with the spirit of the 1978 Amendments to the Act, ${ }^{7}$ and they have been challenged by affected individuals claiming statutory protection. ${ }^{8}$

Courts have heard and at times have sustained employer arguments that rely on the costliness of retaining employees to justify discharges that disproportionately affect older workers. ${ }^{9}$ They have not, however,

Standards administration, Dep't of Labor, Age Discrimination in Employment Act of 1967: A Report Covering Activities Under the ACt During 1973, at vii (1974). Not all violations reach the courts. See ADEA, $\$ 7(d), 29$ U.S.C. $\$ 626$ (d) (1970) (prescribing conciliatory stages that precede actual litigation).

6. In its use of the term "disparate impact," this Note assumes that a finding of statistical significance has been made. For discussion of statistical analysis and employment discrimination law, see Note, Beyond the Prima Facie Case in Employment Discrimination Law: Statistical Proof and Rebuttal, 89 HARv. L. REv. 387 (1975).

7. Age Discrimination in Employment Act Amendments of 1978, Pub. L. No. 95-256, $\S \S 1-7,92$ Stat. 189. The 1978 ADEA Amendments reflect a shift in legislative priorities from promoting the hiring of older workers to preserving their job security. Compare H.R. REP. No. 805, 90th Cong., Ist Sess. 4, reprinted in [1967] U.S. COdE CoNG. \& Ad. News 2213, 2217 (emphasizing as primary purpose hiring older workers) [hereinafter cited as House RePORT 805] with Age Discrimination in Employment Amendments of 1977: Hearings on S. 1784 Before the Subcomm. on Labor of the Senate Comm. on Human Resources, 95th Cong., 1st Sess. 1-2 (1977) (Sen. Williams, Chairman) (key objectives are extending upper limit of protected age range from 65 to 70 and outlawing benefit plans that compel early retirement; both goals relate primarily to problem of job retention among older workers) [hereinafter cited as Senate Hearings on Age Amendments]. Although the Amendments address the issue of protection against involuntary retirement, they are relevant to the problem of discharge based on age-related costs. See pp. 585-86 infra.

This shift in focus was preceded by evidence of growing congressional concern that incumbent older workers not bear a disproportionate share of the burden in an economy experiencing substantial unemployment. See, e.g., Staff of Senate Special Cosm. on Aging, 94th Cong., 2d Sess., Recession's Continuing Victim: The Older Worker v, 14 (Comm. Print 1976) (workers over age 55 worse off now than at height of 1974-75 recession; they experience great difficulty re-entering labor force following layoff or discharge); Staff of Senate Special Comm. on Aging, 92d Conc., 2d Sess., Cancelled Careers: The Impact of Reduction-in-Force Policies on Middle-Aged Federal Employees iii-iv, 1 (Comm. Print 1972) (personnel cutbacks implemented by pressuring older career civil servants into early retirement); cf. Senate Hearings on Age Amendments, supra, at 75 (remarks of Dr. Marc Rosenblum) (experience under ADEA shows its greatest potential lies in protecting existing employees; proposed Amendments represent further effort to stem involuntary outflow of older persons from labor force).

8. See, e.g., Cova v. Coca-Cola Bottling Co., 574 F.2d 958 (8th Cir. 1978); Laugeson v. Anaconda Co., 510 F.2d 307 (6th Cir. 1975). For discussion of the total number of complaints made under the ADEA, see note 56 infra.

9. See, e.g., Price v. Maryland Cas. Co., 561 F.2d 609, 612-13 (5th Cir. 1977) (approving employer's general cost justification of economic hard times); Donnelly v. Exxon Research \& Eng'r Co., 12 Fair Empl. Prac. Cas. 417, 420 (D.N.J. 1974), aff'd mem., 521 F.2d 1398 (3d Cir. 1975) (approving employer reliance on particular cost of higher salaries).

Illegal discharge litigation under the ADEA has primarily concerned nonunionized employees. The Note does not address problems of unionized employees under the Act. See note 75 infra. 
agreed on how to assess the legitimacy of cost as a defense to illegal discharge actions brought under the ADEA. ${ }^{10}$

This Note proposes an approach that would enable a court to analyze the competing interests of an employer's genuine business necessity and an older employee's right to nondiscriminatory treatment. The Note identifies two ways in which employers may argue that older workers cost more to retain than their younger counterparts. The first argument, that older workers create higher "indirect costs" because they are less productive or efficient, is potentially legitimate; but the Note suggests that courts should review such an argument carefully to ensure that individual employee performance evaluations are not conducted in a discriminatory fashion. The remainder of the Note focuses on the second employer argument, that older workers with seniority impose "direct costs" because of their higher salaries and fringe benefits. ${ }^{11}$ The Note concludes that discharges based on these direct costs are very likely to be discriminatorily age-related. When employers defend such discharges as economically essential, the discharges should be upheld only if less detrimental alternatives are not economically practical. ${ }^{12}$ A thorough exploration of alternatives prior to the initiation of discharge action will in many instances allow employers to avoid the expense of litigation under the ADEA.

10. Compare Mastie v. Great Lakes Steel Corp., 424 F. Supp. 1299, 1318 (E.D. Mich. 1976) (statute does not require employer to retain older employecs at economic loss to employer) and Donnelly v. Exxon Research \& Eng'r Co., 12 Fair Empl. Prac. Cas. 417, 422 (D.N.J. 1974), aff'd mem., 521 F.2d 1398 (3d Cir. 1975) (same) with Marshall v. Arlene Knitwear, Inc., 454 F. Supp. 715, 728 (E.D.N.Y. 1978) (sound business judgment not adequate reason for discharge decision when age important factor in that judgment) and LaChapelle v. Owens-Illinois, Inc., 14 Fair Empl. Prac. Cas. 737, 739-40 (N.D. Ga. 1976) (same). The court in Mastie acknowledged the force of ADEA Interpretations, 29 C.F.R. $\$ 860.103(\mathrm{~h})$ (1977), a regulation prohibiting age-based classifications of employees for the purpose of comparing costs. But it concluded that because the regulation referred only to groups of employees, cost was a legitimate ground for discharge when applied on an individual employee basis. 424 F. Supp. at 1319.

Commentators addressing the cost issue have seen little in the ADEA that forecloses an employer's ability to terminate an older worker because his retention is too costly. See Calille, Three Developing Issues of the Federal Age Discrimination in Employment Act of 1967, 54 U. DET. J. URB. L. 431, 440-46 (1977); Note, The Age Discrimination in Employment Act of 1967, 90 HaRv. L. REv. 380, 399 (1976). But cf. Drucker \& Moore, Mandatory Retirement: Past Present and Future of an Anachronism, 5 W. ST. U. L. REv. 1, $41-42$ (1977) (critical of argument that either individual or group cost differentials are legitimate grounds for discharge).

11. See 1976 ADEA ANNUAL RePORT, supra note 5, at 8 (suggesting that employers can make such cost-based discharge decisions during periods of economic downturn). For recognition of the threatening implications to older workers of this direct cost argument, see 124 Cong. Rec. S445I (daily ed. Mar. 23, 1978) (Sen. Stevenson); 123 Cong. Rec. H9968 (daily ed. Sept. 23, 1977) (Rep. Rosenthal).

12. For discussion of the "less detrimental alternative" standard and its Title VII origins, see p. 587 \& note 97 infra. 


\section{Age Discrimination and Cost}

\section{A. Purposes and Application of the ADEA}

In enacting the ADEA, Congress set forth two major purposes as objects of investigation and enforcement. ${ }^{13}$ The Act aims first to encourage and protect the employment of older persons based on ability rather than age. This has been construed officially to mean that age must not be "a determining factor" in an employer's decision regarding the hiring or discharge of an individual. ${ }^{14}$ Courts have concluded that for age to be a determining factor it need only have been one factor among many, provided it made a difference in an employer's decision whether to retain or discharge a worker. ${ }^{15}$ Thus if an older worker's discharge were grounded in part on lack of certain training, and that training had been offered to younger personnel only, discharge of the older employee would be illegal under the Act. ${ }^{10}$

The other major congressional purpose is the prohibition of arbitrary age discrimination in employment. Age-based classifications may be arbitrary when employer assumptions about the effect of advancing age on levels of job performance are devoid of factual basis. ${ }^{17}$ In addition, the ADEA forbids employer generalizations based on accurate data concerning group performance by age because these also constitute arbitrary age discrimination against particular individuals. ${ }^{18}$

13. See ADEA, § 2(b), 29 U.S.C. § 62I(b) (1970). A third purpose, helping employers and workers deal with age-related problems, is addressed primarily through $i d . \$ 3(a), 29$ U.S.C. $\$ 622(a)$, which requires the Secretary of Labor to undertake an education and research program. It has not been the focus of enforcement activities. See 1976 ADEA ANNUAL REPORT, supra note 5, at 7-16.

14. See ADEA Interpretations, 29 C.F.R. $\$ 860.103$ (c) (1977) ("The clear purpose [of Congress] is to insure that age, within the limits prescribed by the Act, is not a de. termining factor in making any decision ....") Reference to the Act's purpose in the legislative history quotes language virtually identical to that in $\$ 860.103$ (c). See S. REP. No. 723, 90th Cong., Ist Sess. 7 (1967).

15. See, e.g., Laugeson v. Anaconda Co., 510 F.2d 307, 317 (6th Cir. 1975) (jury instruc. tion that plaintiff cannot recover unless discharged solely because of age held reversible error); Fellows v. Medford Corp., 16 Fair Empl. Prac. Cas. 764, 766 (D. Or. 1978) (plaintiff wins if age made difference, even as one of many reasons for discharge); Coates v. National Cash Register Co., 433 F. Supp. 655, 660.61 (W.D. Va. 1977) (approving jury instruction that plaintiffs can recover if discharge based "in whole or in part upon age" " or if " "one of the reasons for their discharge was their age" "). But see Brennan v. Reynolds \& Co., 367 F. Supp. 440, 444 (N.D. Ill. 1973) (court construes ADEA as preventing discharge only when based on age alone).

16. See Coates v. National Cash Register Co., 433 F. Supp. 655, 658-59, 661 (W.D. Va. 1977).

17. See U.S. Dep't of Labor, The Older American Worker: Age Discrimination in EMployment, Report of the Secretary of LaboR to the Congress Under Section 715 of the Civil Rights ACT of 1964, at 2 (1965). For a discussion of studies challenging such baseless generalizations, see notes $52-55$ infra.

18. See ADEA $\$ 4(a)(1), 29$ U.S.C. $\$$ 623(a)(1) (1970) (tracking language of $\S 703(a)(1)$ of Civil Rights Act of 1964, 42 U.S.C. $\S 2000 \mathrm{e}-2(\mathrm{a})(\mathrm{I})(1970)$ ); cf. City of Los Angeles, Dep't of 
In order to enforce compliance with its two chief objectives, the Act authorizes an aggrieved employee, or the Secretary of Labor on his behalf, to bring a civil action against the employer. ${ }^{19}$ A necessary first step in such an action is the establishment of a prima facie case of discrimination. In considering what constitutes a prima facie case under the ADEA, courts have required that the plaintiff demonstrate both an employee's membership in the protected age group and his involuntary termination. ${ }^{20}$ They also may require a showing that the employee was doing apparently satisfactory work and that he was replaced by a younger person, although here less uniformity exists among courts. ${ }^{21}$ In addition, a showing that concurrent or recent employee discharges have had a disparate impact on the protected class strengthens the plaintiff's prima facie case.22 Once the plaintiff establishes a prima facie case, the burden of proof shifts to the employer, who must either offer rebuttal evidence tailored to one of the explicit statutory exceptions, ${ }^{23}$ or face liability under the Act.

Water \& Power v. Manhart, 435 U.S. 702 (1978) (under Title VII, fact that women live longer than men cannot justify employer requirement that female employee contribute more to pension fund than male employee).

19. ADEA, § 7(c), 29 U.S.C. § 626(c) (1970). See generally Comment, Procedural Prerequisites to Private Suit Under the Age Discrimination in Employment Act, $44 \mathrm{U}$. CHI. L. REv. 457 (1977).

20. See, e.g., Wilson v. Sealtest Foods Div. of Kraftco Corp., 501 F.2d 84, 86 (5th Cir. 1974). Judicial discussion of what constitutes a prima facie case for illegal discharge under the ADEA often draws upon the Supreme Court's discussion of refusals to hire under Title VII, set forth in McDonnell Douglas Corp. v. Green, 411 U.S. 792, 802 (1973) (to establish prima facie case, complainant must show that he belongs to racial minority, that he applied and was qualified for job, that he was rejected, and that job remained open). In McDonnell Douglas, the Court declared that its four-part test did not establish an immutable definition of a prima facie case, id. at $802 \mathrm{n.13}$, and courts considering discharge complaints under the ADEA have disagreed over whether to adhere strictly to the fourpart framework. See note 21 infra (citing cases).

21. Compare Donnelly v. Exxon Research \& Eng'r Co., 12 Fair Empl. Prac. Cas. 417, 421-22 (D.N.J. 1974), aff'd mem., 521 F.2d 1398 (3d Cir. 1975) (failure to establish satisfactory work performance defeats prima facie case) and Price v. Maryland Cas. Co., 561 F.2d 609, 612 (5th Cir. 1977) (lack of evidence of replacement with younger person defeats prima facie case) with Marshall v. Goodyear Tire \& Rubber Co., 554 F.2d 730, 735.36 (5th Cir. 1977) (implying that plaintiff need not establish satisfactory performance on job) and Bonham v. Dresser Indus., Inc., 569 F.2d 187, 195 (3d Cir.), cert. denied, 99 S. Ct. 87 (1978) (plaintiff need not prove replacement with younger employee).

22. Although a showing of disparate impact on the protected class is not necessary in order for plaintiff to establish a prima facie case, courts often consider the presence or absence of such an impact to be probative. See, e.g., Marshall v. Hills Bros., 432 F. Supp. 1920, 1325 (N.D. Cal. 1977); Schulz v. Hickok Mfg. Co., 358 F. Supp. 1208, 1213 (N.D. Ga. 1973). This Note assumes, for convenience in discussion, that establishment of a prima facie case includes the demonstration of a disparate impact.

23. Because cost does not appear in the Act as a defense against age-related discharges, it must be invoked through one of the recognized statutory exceptions. See 29 U.S.C. $\S 623(\mathrm{f})(1970)$, as amended by Pub. L. No. 95-256, $\S 2,92$ Stat. 189. To qualify for a statutory exception, the employer may admit to discrimination based on age but provide an adequate affirmative justification for $i t$, i.e., that age was a bona fide occupational 
When employee layoffs or discharges are challenged in court, employers often assert that age was not a factor at all and instead appeal to economic necessity or legitimate business priorities, claiming that they fall within the statutory exception for actions based on a "reasonable factor other than age." ${ }^{44}$ In times of economic stress, employers search for ways to cut costs, and substantial personnel reductions are a frequently used means to that end. Because older workers yield to younger ones as a normal incident of the aging process, an employer's decision to hasten attrition without making replacements may be viewed as an acceptable modification of normal labor force turnover. ${ }^{25}$

qualification, $i d$. $\S 623(f)(1)$, or that the discharge was based on a bona fide seniority, pension, or benefit plan that is not a subterfuge, id. $\S 623(f)(2)$. Alternatively, he may deny that age discrimination was present at all, arguing that the discharge was for good cause, id. $\S 623(\mathrm{f})(3)$, or was based on reasonable factors other than age, id. $\S 623(\mathrm{f})(\mathrm{I})$.

24. ADEA, § 4(f)(1), 29 U.S.C. $\$ 623(f)(1)$ (1970); see, e.g., Schulz. v. Hickok Mfg. Co., 358 F. Supp. 1208 (N.D. Ga. 1973); Stringfellow v. Monsanto Co., 320 F. Supp. 1175 (W.D. Ark. 1970). The "reasonable factors" exception is the only one applicable in this context of business necessity, and is the one regularly resorted to by employers and courts. The others are inapposite.

The "good cause" exception, 29 U.S.C. $\$$ 623(f)(3) (1970), like "reasonable factors," denies the presence of any age discrimination at all. On occasion, courts have cited the two exceptions interchangeably. See, e.g., Bittar v. Air Canada, 512 F.2d 582, 583 (5th Cir. 1975) (affirming 10 Fair Empl. Prac. Cas. 1136, 1137 (S.D. Fla. 1974)) (court of appeals used term "reasonable factors"; district court used term "good cause"). The "reasonable factors" exception is meant to cover a termination resulting from criteria or measurements that are applied to all employees and prompted by considerations unrelated to one individual's changing performance level. See ADEA Interpretations, 29 C.F.R. $\$ 860.103(f)$ (1977) (physical fitness test, performance evaluation criteria). In contrast, "good cause" traditionally refers to management's prerogative to initiate termination of a demonstrably incompetent worker. The termination represents an employer decision, unprompted by outside forces, that an individual employee has ceased to meet minimum performance expectations. See, e.g., Randlett v. Owens-Illinois, Inc., 419 F. Supp. 103 (N.D. Tex. 1976); Brennan v. Reynolds \& Co., 367 F. Supp. 440 (N.D. Ill. 1973). Although the individual termination may improve overall efficiency (and thereby cut cost), it is unrelated to the employer's threshold defense of "economic necessity" as a "reasonable factor other than age."

Under the "bona fide occupational qualification" (BFOQ) exception, 29 U.S.C. $\$ 623$ (E)(1) (1970), an employer sanctions discriminatory impact by making age a BFOQ in the interest of promoting an objective reasonably necessary to the normal operation of his particular business, such as public safety in the operation of a common carrier. Courts have not referred to the cost factor in BFOQ caselaw. See, e.g., Houghton r. McDonnell Douglas Corp., 553 F.2d 561 (8th Cir.), cert. denied, 434 U.S. 966 (1977).

The "bona fide seniority system or employee benefit plan" exception, as recent amendments to the ADEA make clear, does not apply to any plan that requires or permits management to force early retirement because of age. 29 U.S.C. $\$ 623(f)(2)$ (1970), as amended by Pub. L. No. 95-256, § 2(a), 92 Stat. 189 (1978); see H.R. REP. No. 950, 95th Cong., 2d Sess. 1, 8 (1978) (conference report); cf. note 93 infra (discussing unsuccessful efforts to justify age-based forced retirements on grounds of cost).

25. Cf. Marshall v. Goodyear Tire \& Rubber Co., 554 F.2d 730, 736 (5th Cir. 1977) (replacement of older employee raises lesser inference of discriminatory motive than does replacement of black employee in Title VII cases; employer bears lesser burden of proof in responding to prima facie case under ADEA). Contra, Marshall v. Arlene Knitwear, Inc., 454 F. Supp. 715, 728 (E.D.N.Y. 1978). 
An employer nevertheless retains a burden of advancing a nondiscriminatory basis for discharges that rest on the "reasonable factors" exception. ${ }^{26}$ In relying on this exception, the employer is asserting both the existence of an economic interest and the use of nondiscriminatory means to advance that interest. Because the two assertions are distinct, the defendant-employer bears a burden of proof with respect to each.

In citing adverse business conditions to justify layoffs or discharges, ${ }^{27}$ an employer faces only a minimal burden of adducing evidence to support his economic purpose. ${ }^{28} \mathrm{~A}$ rational employer will usually act out of economic self-interest, and the societal value placed on free enterprise militates against judicial oversight of private business decisions. Because the employer has greater access to economic evidence than do employees or courts, and because his decisions are alleged ultimately to have injured a class that society seeks to protect, he does have an obligation to explain his actions. But absent a substantial indication of bad faith, ${ }^{29}$ virtually any explanation, will be "reasonable." 30

After a defendant-employer proves the existence of an economic interest, he must demonstrate its relevance to his particular discharge

26. Although the usual tendency in civil cases is to allocate burdens of proof to the party desiring change, the apportionment of burdens in federal employment discrimination cases departs from this norm. See Note, supra note 10, at 388 (Title VII). Compare McCormick's H.ANdBook of the LAw of Evidence $\$ 337$, at 786 (E. Cleary $2 d$ ed. 1972) [hereinafter cited as McCormick] with MIcDonnell Douglas Corp. v. Green, 41 I U.S. 792, 800-03 (1973). Congress's remedial objectives, expressly relied on by courts in transferring to employers a burden to explain apparently discriminatory conduct in Title V'II cases, are present under the ADEA as well. Lorillard v. Pons, 434 U.S. 575, 584 (1978); see ADEA Interpretations, 29 C.F.R. $\$ 860.103(\mathrm{c})$ (1977) (burden of proof in establishing applicability of "reasonable factors" exception rests on employer); cf. A. H. Phillips, Inc. v. Walling, 324 U.S. 490, 493 (1945) (exemption from remedial labor legislation must be narrowly construed). But see note 34 infra (citing conflicting cases); Note, supra note 10, at 392-98 (arguing that burden of persuasion should remain with plaintiff under ADEA).

27. Judicial discussion of an employer's claimed adverse business conditions has not distinguished between the fear of imminent total business failure and a desire for more streamlined business operations that will effect modest savings. This Note argues that the magnitude of economic adversity should be a threshold consideration when the dis. parate impact of discharges is predictably age-related. See pp. 588-90 infra.

28. See, e.g., Reed v. Shell Oil Co., 14 Fair Empl. Prac. Cas. 875, 877 (S.D. Ohio 1977) (right of defendant to reduce work force in light of adverse conditions in petroleum industry cannot be questioned); Mastic v. Great Lakes Steel Corp., 424 F. Supp. 1299, 1302 (E.D. Mich. 1976) (accepting defendant's decision to curtail operations on grounds of economic necessity).

29. See, e.g., Marshall v. Arlene Knitwear, Inc., 454 F. Supp. 715, 724-27 (E.D.N.Y. 1978) (employer carried out purported business dissolution, then reformed company under new name, and rehired younger workers while not informing older worker of new company's existence). In general, however, no disparate impact follows simply from an employer's economic need to make personnel reductions.

30. See Bishop v. Jelleff Assocs., 398 F. Supp. 579, 593 (D.D.C. 1974) (so long as decision to terminate workers made in good faith with rational basis, court will not judge wisdom of such business decision). 
selections. ${ }^{31}$ Although the assertion of a general economic need to reduce personnel is in itself neutral, the employer's choice of older workers in disproportionate numbers causes immediate injury to members of the protected class. The ostensible basis for such discharges is usually some form of comparative employee evaluation. ${ }^{32}$ But given a direct impact on the statutorily protected class, and the possibility that the evaluation process may conceal discriminatorily age-related selections, a court will require an employer to establish more than he did regarding his reasonable business purpose. ${ }^{33}$ Although the courts have not agreed on precisely how great a showing is required, ${ }^{34}$ an employer relying on cost as a "reasonable factor other than age" must at least rebut the presumption that age itself played a determining role in his implementation decisions. ${ }^{35}$

\section{B. The Element of Cost}

Reliance on the cost factor to justify termination of older workers takes one of two forms. An employer may claim that there are direct

31. See id. at 594 (legitimate business purpose must still be implemented in nondiscriminatory fashion).

32. The scope of employee evaluation and the nature of evidence supporting a discharge decision vary widely. Compare Stringfellow v. Monsanto Co., 320 F. Supp. 1175 (W.D. Ark. 1970) (formal evaluation plan, derived from recognized professional source, featuring 18 criteria for determining individual job performance) with Cova v. CocaCola Bottling Co., 574 F.2d 958 (8th Cir. 1978) (personal evaluations by newly appointed general sales manager).

33. For instances in which age was held an improper factor despite the presence of a formal employee evaluation, see, e.g., Mistretta v. Sandia Corp., 15 Fair Empl. Prac. Cas. 1690 (D.N.M. 1977); Schulz v. Hickok Mfg. Co., 358 F. Supp. 1208 (N.D. Ga. 1973).

34. The courts have split over the question of the weight of an employer's "nondiscriminatory implementation" burden in response to a prima facie case under the ADEA. Compare Moses v. Falstaff Brewing Corp., 550 F.2d 1113, 1114 (8th Cir. 1977) (establishment of prima facie case shifts burden to employer to justify existence of any disparities) and Marshall v. Arlene Knitwear, Inc., 454 F. Supp. 715, 728 (E.D.N.Y. 1978) (burden of persuasion shifts following prima facie showing under ADEA, just as it does under Title VII) with Marshall v. Westinghouse Elec. Corp., 576 F.2d 588, 590.92 (5th Cir. 1978) (prima facie showing under ADEA shifts burden of production to employer, but ultimate burden of persuasion remains with plaintiff) and Laugeson $v$. Anaconda Co., 510 F.2d 307, 313 (6th Cir. 1975) (same). At least one court has stated that the practical significance of the weight assigned is often minimal. See Mastie v. Great Lakes Steel Corp., 424 F. Supp. 1299, 1308 (E.D. Mich. 1976). Even satisfying a burden of production in the face of opposing presentations requires more than the scintilla of evidence traditionally accepted with regard to unopposed assertions of economic purpose. See McCoRMICK, supra note $26, \S 338$, at 789 .

35. See generally McCoRmick, supra note $26, \$ \S 338$, 342. Under the procedure adopted for race discrimination cases in McDonnell Douglas Corp. v. Green, 411 U.S. 792, 802-05 (1973), a defendant's evidence of nondiscriminatory implementation in response to plaintiff's prima facie case does not conclude the proceeding. The plaintiff retains an opportunity to show that defendant's nondiscriminatory justification was a pretext, or was discriminatory in its application. For a discussion of this final stage with respect to performance-based reductions in personnel, see pp. 578-80 infra. 
costs resulting from retention of older workers with accumulated job tenure. Specifically, senior workers draw higher salaries and their presence may require employers to contribute at a higher level to various fringe benefits. ${ }^{36}$ Alternatively, an employer may allege that retention of older workers costs him indirectly in terms of his goods or services. Thus he may claim that his older employees are less productive, have higher rates of absenteeism, or display less adaptability. to changing job requirements. ${ }^{37}$

On both the direct and indirect levels, cost as a "reasonable factor other than age" offers some appeal in relation to the Act's two major purposes. An employer is able to point to particular employees with higher salaries than others performing the same job. Discharge of the more expensive individuals does not seem arbitrary. In addition, the higher direct cost of an older worker can be translated into a "productivity per dollar" rationale, suggesting that an employee's ability rather than his age is the determining factor in a discharge decision. Finally, when some employees are judged costly because of comparatively low performance ratings, age appears to play no part at all.

Yet cost-induced terminations based on comparative assessments of productivity, efficiency, or versatility often have a disparate impact on older workers. ${ }^{38}$ Similarly, termination of employees who command higher salary or benefit levels within a given job category also may have a disproportionate effect. ${ }^{39}$ In many cases, the presence of such a

36. See notes 75.76 infra. As an immediate consequence of higher salaries, the employer contributes greater amounts to FICA (Social Security) and to unemployment insurance, both of which are computed at fixed percentages of salary. The relation between age and employer pension costs or health insurance costs is less clear. See U.S. DEP'T OF Labor, The Older American Worker: Age Discrimination in EMployment, Report OF the Secretary of Labor to the Congress Under SEction 715 of the Civil Rights ACT OF 1964, Research Materials 40-51 (1965) [hereinafter cited as $\$ 715$ Research Materials].

37. See, e.g., Mistretta v. Sandia Corp., 15 Fair Empl. Prac. Cas. 1690, 1707 (D.N.M. 1977) (employer views older nonsupervisory employees as unproductive and technically obsolete); LaChapelle v. Owens-Illinois, Inc., 14 Fair Empl. Prac. Cas. 737, 739 (N.D. Ga. 1976) (employer business judgment that training younger person of equal skills for expanded responsibilities of position was preferable to retaining older incumbent). Employer claims of indirect cost involve comparisons among workers previously recognized as meeting minimum standards of performance. Such comparisons are prompted by the appearance of economic difficulties rather than the perception of decline in employee performance. See note 24 supra (distinguishing "good cause" exception).

38. See, e.g., Laugeson v. Anaconda Co., 510 F.2d 307, 310-11 (6th Cir. 1975) (reduction from 15 to nine salaried employees following managerial evaluation; average age lowered from 43 to 37); Schulz v. Hickok Mfg. Co., 358 F. Supp. 1208, 1213 (N.D. Ga. 1973) (average age of eight district managers fell from 53 to 41 after reorganization). Substantial personnel reductions having a disparate impact, although ostensibly based on "productivity" or "efficiency," give rise to the suspicion that an employer has ap. plied the stereotype of older workers as less productive or efficient. See pp. 578-80 infra.

39. See Mastie v. Great Lakes Steel Corp., 424 F. Supp. 1299, $1317-19$ (E.D. Mich. 1976) (discharge of two oldest employees from pool of 19; court cited retention costs 
disproportionate effect gives rise to the presumption that age played some role in an employer's particular discharge selections. ${ }^{40}$ Although this presumption may be rebutted by employer reliance on direct or indirect costs as a "reasonable factor other than age," the suspicion that an employer's cost argument itself may conflict with one of the Act's two major purposes merits further examination.

\section{Analysis of the Cost Factor}

\section{A. Judicial Response to Cost in the Discharge Context}

Most of the ADEA caselaw on cost-induced discharges concerns reasonable factor defenses based on the indirect costs of allegedly inferior job performance by older workers. Courts ordinarily are faced with an employer's purportedly formal and objective evaluation procedure ${ }^{41}$ applied as an economy measure. ${ }^{42}$ In reviewing this procedure under a standard calling for nondiscriminatory implementation of legitimate business purposes, many courts have held that the defendant-employer successfully demonstrated an objective evaluation system properly applied, and that the disparate impact was wholly fortuitous. ${ }^{23}$ In several cases, however, courts have held employee evaluations to be insufficiently objective or job-related, and have concluded that the disparate impact does indeed reflect unlawful age discrimination.44

There have been far fewer cases adjudicated on the question of higher direct costs as a ground for discharging older workers. In one recent decision, Marshall v. Arlene Knitwear, Inc., ${ }^{45}$ the district court found an employer in violation of the ADEA for terminating an older worker when the employer's savings from eliminating a high salary level and recouping unpaid pension benefits were "the controlling

associated with projected increase in their pension benefits as factor); cf. Marshall v. Arlene Knitwear, Inc., 454 F. Supp. 715 (E.D.N.Y. 1978) (high salary of older employee primary reason for discharge). For discussion of age as "a determining factor" in such circumstances, see pp. 581-83 infra.

40. See note 22 supra.

41. Courts have differed over whether to accept informal or subjective evaluation criteria. Compare Cova v. Coca-Cola Bottling Co., 574 F.2d 958, 961 (8th Cir. 1978) wilh Mistretta v. Sandia Corp., 15 Fair Empl. Prac. Cas. 1690, 1711 (D.N.M. 1977).

42. See, e.g., Price v. Maryland Cas. Co., 561 F.2d 609 (5th Cir. 1977) (reliance on gross productivity figure); Gill v. Union Carbide Corp., 368 F. Supp. 364 (E.D. Tenn. 1973) (use of standardized rating system).

43. See, e.g., Gill v. Union Carbide Corp., 368 F. Supp. 364 (E.D. Tenn. 1973); Stringfellow v. Monsanto Co., 320 F. Supp. 1175 (W.D. Ark. 1970).

44. See, e.g., Bishop v. Jelleff Assocs., 398 F. Supp. 579 (D.D.C. 1974); Schulz v. Hickok Mfg. Co., 358 F. Supp. 1208 (N.D. Ga. 1973).

45. 454 F. Supp. 715 (E.D.N.Y. 1978). 
economic factors" behind the decision to terminate.46 Yet other courts have approved discharges that rely wholly or in part on higher salaries or fringe benefits of older workers, either by identifying the higher cost as a reasonable factor other than age ${ }^{t 7}$ or by holding that on a productivity-per-dollar basis the plaintiff failed to establish the "doing satisfactory work" element of his prima facie case. ${ }^{48}$

Given a climate of economic urgency, the employer may view himself as forced to choose between according special protection to one group and acting rationally to revive or rescue his business. There is no judicial consensus as to how the Act's purposes should be interpreted to resolve this dilemma. Nor is there reason to assume that a single solution must apply to both direct and indirect cost arguments.

\section{B. Indirect Cost Elements as "Reasonable Factors"}

When an employee is discharged as part of a merit-based reductionin-force, the problem is not that he has become incapable of doing his job. The pool of employees from which discharge selections are made virtually always includes only individuals who are presumptively competent, because they have been employed until the present economic

46. Id. at 730; cf. Naton v. Bank of Cal., No. C-76.944 (N.D. Cal. Nov. 11, 1977), appeal docketed, No. 78.1059 (9th Cir. Jan. 11, 1978) (jury verdict awarding, inter alia, back pay, front pay, and reinstatement in retirement plan to victim of discriminatory layoff); Opening Brief for Plaintiff-Appellee at 18, Bank of Cal. v. Naton, No. 78-1059 (9th Cir., filed Jan. 11, 1978) (summarizing evidence presented at trial linking layoffs to higher costs of retaining older employees).

47. Mastie v. Great Lakes Steel Corp., 424 F. Supp. 1299, 1318-19 (E.D. Mich. 1976) (alternative holding).

48. Donnelly v. Exxon Research \& Eng'r Co., 12 Fair Empl. Prac. Cas. 417, 418, 421-22 (D.N.J. 1974), aff'd mem., 521 F.2d 1398 (3d Cir. 1975); see p. 569 supra (discussing elements of prima facie case under ADEA).

In addition to the few judicial decisions, employers have on several occasions entered into pretrial settlements with the government under which they have paid substantial monetary damages to older employees laid off or discharged apparently as an economy measure. See, e.g., Brennan v. Anaconda Aluminum Co., No. 7835-B, stipulation II 3 \& 4(b) (W.D. Ky. June 4, 1974) (awarding $\$ 60,000$ to 12 employees allegedly terminated unlawfully; defendants agreed to implement affirmative action program, including, inter alia, avoidance of personnel decisions based on such age-related factors as increased salary due to seniority); Brennan v. Western Operations, Inc., No. C-74-1039, judgment at 2 (N.D. Cal. May 15, 1974) (awarding $\$ 2$ million to 160 former employees, and ordering reinstatement of 120 of them); Hodgson v. Pan Am. World Airways, No. 72-839, stipulation at 2 (S.D. Fla. Oct. 16, 1972) (awarding $\$ 250,000$ to 29 former employees allegedly laid off, discharged, or assigned to inactive status because of age); cf. 96 DAILY LAB. REP. (BNA) A-11 (May 16, 1974) ("educated guess" by Solicitor of Labor when questioned about motivation for discharges in Western Operations case: "The layoffs resulted from economic concerns of the company. It was able to replace older workers with younger ones at lower wages. Some of the employees were discharged just before they would have vested rights to their pensions.' ") 
emergency. ${ }^{49}$ The problem is rather that the employer, as a result of overriding economic considerations, has decided to cut back the jobs that the employee and others now do. In deciding whether the layoff or discharge of older employees constitutes illegal age discrimination, a court must focus on the criteria and procedures used to assess the relative competence of workers.

Older workers, in alleging age discrimination, raise a challenge to the performance evaluations that have resulted in their discharge. They argue in effect that because there is no demonstrable link between advancing age within the range protected by the Act and declining efficiency or productivity, no disparate impact should result from job evaluations applied to all employees.

Available research findings lend support to this argument. Although physiological changes occur as part of the aging process, ${ }^{50}$ chronological age is widely recognized as an unsatisfactory predictor of job performance. ${ }^{51}$ The few studies conducted on worker productivity in particular occupations or industries tend to confirm an absence of meaningful connection between advancing age and declining levels of job performance. ${ }^{52}$ Efforts to investigate older workers' patterns of absen-

49. See, e.g., Defendants' Post-Trial Memorandum at 2, 10, Marshall v. Baltimore \& O.R.R., No. 74-637 (D. Md., filed June 18, 1974) (defendant terminated 142 noncontract employees over age 60 , claiming business necessity; effort to identify poor performers as initial focus of reduction led to identification of less than one percent of noncontract workforce); $c f$. J. Northrup, Old Age, Handicapped \& Vietnam Era ANtiDISCRIMINATION LEGISLATION 33 (1977) (inability to perform careful merit analysis during sizeable reduction-in-force often leads to termination of good workers).

50. See, e.g., J. MANNey, Aging in American Society 25 (1975) (metabolic efficiency declines about $10 \%$ between ages 30 and 80 ; breathing capacity and kidney function decline by half over same period; cholesterol concentration peaks at about age 55 and declines sharply thereafter; body's ability to regulate glucose levels unchanged with age, although rate at which normal levels are restored following sharp rise becomes slower with age); A. Welford, Ageing and Human Skill 283-85 (1958) (test results show slowing of performance with age, in both mental and sensory-motor areas); Green, Age, Intelligence and Learning, Indus. Gerontology, Winter, 1972, at $39-40$ (I.Q. test scores probably decline "sooner or later," and some decline in ability to learn occurs after age 60).

51. See Retirement Age Policies (Part II): Hearings Before the House Select Comm. on Aging, 95th Cong., lst Sess. 85 (1977) (remarks of Dr. Harold Sheppard) (chronological age per se is poor indicator of job performance; citing improvement of health and education levels for those over 60 and substantial decline in physically onerous nature of jobs). Studies have found enormous variation among individuals with respect to the chronological age at which particular changes take place. See A. Heron \& S. Chown, Age ANd Function 137 (1967); A. Welford, supra note 50, at 283. Comparable variation exists with respect to the effects of physiological changes on performance levels. See Birren, Age Changes in Skill and Learning, in EARNINg OpPortunities FOR OLder WORkERs 67 (W. Donahue ed. 1955); Green, supra note 50, at 40. Finally, many older individuals are able to compensate for such changes on the job. See J. ManneY, supra note 50, at 25; A. Welford, supra note 50 , at 286.

52. In the areas of office and clerical work and retail sales older workers were found to be as productive as, or more productive than younger workers. See U.S. DEP'T of 
teeism, ${ }^{53}$ accident rates on the job, ${ }^{54}$ and ability to be trained for new jobs, ${ }^{65}$ all indicate that older workers are as efficient and capable as their younger counterparts. In short, the available evidence suggests little reason why, at the time of an economically induced personnel cutback, the "less competent employees" should turn out to be older workers.

Yet the presence of the Act itself, the steady rise in the total number of complaints received, ${ }^{56}$ and the growing administrative attention to

Labor, Questions and Issues Relating to Proposed Amendments to the Age DiscriminAtion In EMPLOYMENT ACt of 1967, Report to the SUbCOMM. ON LABOR, UNited States Sendte Comm. ON Human Resourses app. A, at 13 (1977) (citing N.Y. State Div. of Human Rights, Survey of State Agencies Concerning the EMployment of Older Workers (1972)) (state agency employees aged 65-70); U.S. BurEau of Labor Statistics, Dep't of Labor, Bull. No. 1273, Comparative Job Performance by Age: Office Workers 1-2 (1960) (office workers over age 45); $\$ 715$ RESEARCH MATERIALs, supra note 36, at 86-87 (summarizing Economics and Research BRANCh, Canadian Dep'T of LaboR, Age and Performance in Retall Trade (1959)) (sales personnel over age 50); Arvey \& Mussio, Test Discrimination, Job Performance and Age, Indus. Gerontology, Winter, 1973, at 27 (clerical workers over age 50). In areas of work entailing substantial physical effort, there is some conflict in the evidence, but the focus of this conflict is on production decline after age 65. Compare U.S. Bureau of Labor Statistics, Dep'T of Labor, Buly. No. 1223, Comparative Job Performance By Age: Large Plants in the Men's Footwear AND Household FURNiture Industries 1 (1957) (slight decrease in productivity after age 45, decrease substantial after age 65) with Schwab \& Heneman, Effects of Age and Experience on Productivity, Indus. GerontoLOGY, Spring, 1977, at 115-16 (no significant difference in productivity between industrial workers under age 29 and those over 54) and Palmer \& Brownell, Influence of Age on Employment Opportunities, 48 MonTHL. LAB. REv. 765, 775-76 (1939) (446 textile weavers, spinners, and workers in nonferrous metal company studied; no correlation between age and output found).

53. See, e.g., Kossoris, Absenteeism and Injury Experience of Older Workers, 67 Monthly LAB. Rev. 16, 16-17 (1948) (number of days lost per 100 workdays decreases with advancing age).

54. See, e.g., id. at 17-18 (only disadvantage of older workers with respect to injuries is tendency to be disabled longer once injured; injury frequency rate generally declines with age); McFarland, The Need for Funclional Age Measurements in Industrial Gerontology, Indus. Gerontolocy, Fall, 1973, at 9 (citing L. Norman, Professional Drivers and Road Safety, in Proceenings of the Second Congress of the International AssociaTION FOR ACcidents ANd TRAFfic Medicine (1966)) (London bus drivers age 60-64 had lowest average number of accidents).

55. Although sources conflict on the question of whether older workers are in fact less able to be trained, more recent studies suggest that any age differential is of minimal importance. Compare Haberlandt, Learning, Memory and Age, Indus. Gerontology, Fall, 1973 , at 30 (in shifting from established to new skill, workers over age 45 perform as well as younger employees when extreme speed of performance not essential factor) and Belbin, Book Review, Indus. Gerontolocy, Oct. 1969, at 32-33 (reviewing Newsham, The Challenge of Change to the Adult Trainee) (Newsham found trainees over age 35 have longer expectation of employment tenure within company than younger trainees) with R. Brldin, Training Methods for Older Workers 66.67 (1965) (slower learning rates of older adults in routine training courses may be offset by potentially costly changes in training approaches; cost differential expected to diminish as knowlcdge of adult training methods increases).

56. See Senate Hearings on Age Amendments, supra note 7, at 26 (number of complaints up $400 \%$ in seven years, from 1,031 in 1969 to 5,121 in 1976; rise attributed to number of factors, including recent recession and inadequate economic growth); $c f$. note 5 supra (number of identified discharge violations also increased). 
problems of illegal discharge, ${ }^{57}$ all suggest that in many instances older employees are victimized by discriminatory personnel judgments. Employers confronted with specific prima facie cases usually point to individual evaluations as a defense and disavow any reliance on arbitrary stereotypes. They may cite formal evaluation records and procedures as probative of good faith efforts to reach difficult personnel verdicts. ${ }^{58}$ Reliance on these techniques for individual evaluation may enable an employer to rebut the presumption of discriminatory implementation, but should not necessarily determine the final outcome.

Because general empirical findings on older workers' performance are so often at odds with employer behavior that is allegedly a response to such performance, there is a need to look beyond announced evaluation results in deciding whether particular discharges are discriminatory. Judicial analysis of shifts in the burden of proof under Title VII provides a useful analogy. ${ }^{59}$ Under Title VII, an employee who has established a prima facie case of race or sex discrimination must be given an opportunity to demonstrate that his employer's stated reason for termination was in fact a pretext for discrimination or was discriminatorily applied. ${ }^{60}$ By granting this opportunity the Supreme Court has recognized that an employer's assumptions and actions toward a protected group may undercut his presumptively nondiscriminatory motives with regard to an individual member of the group. ${ }^{61}$

Similar analysis should be applied under the ADEA. Employer assumptions about the influence of age on a person's ability to perform $\mathrm{a}$ job are at the core of age discrimination in employment. ${ }^{62}$ These

57. See U.S. Employment Standards Administration, Dep't of Labor, Age Discrimination in EMployment Act of 1967: A Report Covering Activities Under the Act DuRING 1977, at 17, 25-26 (1978) (shift in emphasis to development of large pattern or practice cases). Cases alleging a general pattern or practice of age discrimination tend to involve layoffs and terminations. See, e.g., Marshall v. American Motors Corp., No. 771249 (E.D. Mich., filed May 20, 1977); Marshall v. Pan Am. World Airways, No. 75-2559 (S.D.N.Y., filed May 30, 1975).

58. See [1978] I LAB. ReL. REP. (BNA) (98 Analysis) 9, 12 (review of court decisions suggests employer's chances of successfully rebutting prima facie illegal discharge case increase when he produces documentation of formal evaluations).

59. Cf. Lorillard v. Pons, 434 U.S. 575, 584 (1978) (important similarities in overall purpose and substantive prohibitions between ADEA and Title VII). Some courts have found these similarities to bear directly on burden-of-proof issues. See, e.g., Reed v. Shell Oil Co., 14 Fair Empl. Prac. Cas. 875, 877 (S.D. Ohio 1977) (adopting approach of McDonnell Douglas Corp. v. Green, 411 U.S. 792 (1973)).

60. McDonnell Douglas Corp. v. Green, 411 U.S. 792, 804-06 (1973).

61. See $i d$. (employer's general policy and practice with respect to minority employment fact relevant to showing of pretext).

62. During the legislative process culminating in enactment of the ADEA, it was widely observed that in contrast to race discrimination, there is virtually no consciousness of prejudice with regard to age, except as it relates to job ability. See, e.g., Age Dis- 
beliefs may amount to pervasive yet unconscious stereotypes ${ }^{63}$ that lead either to good faith application of unintentionally discriminatory performance assessments, ${ }^{64}$ or to application of an intentional policy preference for younger workers that employers do not consider discriminatory. ${ }^{65}$ Whatever the level of employer awareness, these assumptions are hard to detect precisely because they are so intimately related to other judgments about employment. Courts may be misled by the performance evaluation defense and should therefore inquire closely into the possibility that the evaluation process is itself discriminatory.

Once a court recognizes the presence of discriminatory implementation of an employer's performance evaluation, the plaintiff should be deemed to have satisfied his burden of proof. ${ }^{66}$ Although a court should not be expected to delve into the subconscious motivation underlying every personnel decision, the presence of certain factors raises a strong suggestion of discriminatory implementation. ${ }^{67}$ Among factors

crimination in Employment: Hearings on H.R. 3651, H.R. 3768, \& H.R. 4221 Before the General Subcomm. on Labor of the House Comm. on Education d Labor, 90th Cong., 1st Sess. 13 (1967) (remarks of Sec'y of Labor Wirtz) [hereinafter cited as 1967 House Hearings]; 113 CoNG. Rec. 34,742 (1967) (Rep. Burke); id. at 34,752 (Rep. Dwyer). One implication of this difference is that detecting the presence of age discrimination on the job will often be difficult. See generally 1967 House Hearings, supra, at 45 (remarks of Norman Sprague).

63. See, e.g., Amendments to the Age Discrimination in Employment Act of 1967: Hearing on H.R. 65 \& H.R. 1115 Before the Subcomm. on Employment Opportunities of the House Comm. on Education \& Labor, 95th Cong., 1st Sess. 99 (1977) (statement of D. E. Knowles, personnel director for Grumman Aerospace Corp.) ("If the average company were asked if it discriminates against middle-aged and older workers, I'm sure it would reply with righteous indignation that it doesn't .... [P]robably not one company in ten thousand companies has ever researched their [sic] own organization .... [C]ompanies are discriminating and aren't even aware of it."); Rosen \& Jerdee, Too Old or Not Too Old, HARv. Bus. REv., Nov.-Dec. 1977, at 98 (differential treatment by managers results from unconscious age stereotypes).

64. See, e.g., 1967 House Hearings, supre note 62, at 192 (California legislative report on age discrimination cites "hidden discrimination" of employer physical and educational requirements that require more than necessary for job, with consequent disparate impact); Rosen, Management Perceptions of Older Employees, Monthly Lab. Rev., May 1978, at 34 (managerial reaction to hypothetical involving clerk unresponsive to customer calls indicated that younger employee would receive encouraging talk, but older employee would be labelled resistant to change and possibly reassigned).

65. See, e.g., Bishop v. Jelleff Assocs., 398 F. Supp. 579, 590 (D.D.C. 1974) (employer assumption that older sales employees would frustrate business decision to appeal to younger clientele); cf. Diaz v. Pan Am. World Airways, 442 F.2d 385, 387-88 (5th Cir.), cert. denied, 404 U.S. 950 (1971) (rejecting as "tangential" expert testimony that female attendants better able to meet psychological needs of passengers).

66. Cf. McDonnell Douglas Corp. v. Green, 411 U.S. 792, 807 (1973) (court must order prompt and appropriate remedy upon showing of discriminatory application under Title VII).

67. See notes 68-70 infra (citing cascs). None of these cases refers to the evaluation defense as a "pretext"; the courts decided for plaintiffs on the ground that defendants did not meet their burden of proof. But the employer's contention in each instancethat discharged employces were deemed "less capable" after economic necessity triggered 
that courts have accepted as discriminatory are application of evaluations on a less than uniform basis, ${ }^{68}$ reliance on an evaluation procedure that has age as a built-in component, ${ }^{09}$ and use of the evaluation itself as a pretext for management concern with the prospects of younger employees. ${ }^{70}$ These examples suggest that courts are capable of conducting a sophisticated and vigilant review of performance evaluation procedures and standards. Courts have recognized the need for such sophistication and vigilance in reviewing other employment personnel practices that may discriminate subtly yet pervasively against a protected group of employees. ${ }^{71}$

A finding of discrimination in a performance evaluation means not only that evidence of "lesser productivity" is inadequate, but also that no economic justification exists for discharging older workers under the "reasonable factors" exception. Thus, although the defense of indirect cost is conceptually legitimate, ${ }^{72}$ its improper application would perpetuate age discrimination for no reason other than to satisfy an employer's conscious or unconscious prejudices. In addition, employers

the evaluation itself-arguably meets the McDonnell Douglas requirement that the employer "articulate some legitimate, nondiscriminatory reason for the employee's rejection." 411 U.S. at 802 (emphasis added). In light of the current conflict as to the nature of defendant's burden of proof in rebuttal, see note 34 supra, recognition of plaintiff's opportunity to challenge defendant's proffered nondiscriminatory reason may focus judicial review more effectively on the possibility of discriminatory implementation.

68. See Schulz v. Hickok Mfg. Co., 358 F. Supp. 1208, 1215-16 (N.D. Ga. 1973) (plaintiff's objective performance figures better than those of company as whole, though not up to projections set for his district; court rejects performance assessment defense, impliedly relying on fact that defendant was not making uniform use of evaluation data).

69. See Hays v. Republic Steel Corp., 12 Fair Empl. Prac. Cas. 1640, 1647-48 (N.D. Ala. 1974), aff'd in part and rev'd in part on other grounds, 531 F.2d 1307 (5th Cir. 1976) (discharge of two older workers held violation of Act when only plausible basis for lower performance ratings was long-range potential value to company); Coates v. National Cash Register Co., 433 F. Supp. 655, 661 (W.D. Va. 1977) (plaintiffs discharged based on lack of training with new machinery; court found this attributable to earlier age-based determinations of training eligibility).

70. See Hannan v. Chrysler Motors Corp., 443 F. Supp. 802, 803.05 (E.D. Mich. 1978) (employer followed reduction-in-force policy of retiring workers over age 55 but laying off younger workers subject to recall; court rejected employer assessment of older plaintiff as unsatisfactory employee who would not have been recalled in any event); Mistretta v. Sandia Corp., 15 Fair Empl. Prac. Cas. 1690, 1707 (D.N.M. 1977) (court rejected performance ratings as justification for layoff of 200 older workers, relying in part on evidence of management attitude favoring "new blood").

71. See, e.g., Douglas v. Hampton, 512 F.2d 976, $985-86$ (D.C. Cir. 1975) (government cannot rely on demonstration of "construct" validity of federal service entrance examination challenged under Title VII unless it first shows proof of "cmpirical" validity infeasible); Diaz v. Pan Am. World Airways, 442 F.2d 385, 388 (5th Cir.), cert. denied, 404 U.S. 950 (1971) (employer must prove sex-based aspects of job of flight cabin attendant essential to performance, rather than merely sound business practice, in order for sex to qualify as BFOQ).

72. There is nothing intrinsically age-related about an employer faced with the need to reduce personnel who determines that an individual older employee really is less productive or versatile, and then acts on his determination. 
wishing to protect or encourage their younger personnel are likely to rely more heavily on this defense if they cannot depend on direct cost arguments. ${ }^{73}$ Close judicial attention to allegedly neutral performance evaluations in a business necessity context is therefore warranted.

\section{Direct Cost Elements as "Reasonable Factors"}

Disproportionate termination of workers who happen to be older, based on the comparatively greater expense involved in keeping them on the payroll, does not raise problems of pretext or unconscious stereotyping by employers. The costs of salaries and fringe benefits are objectively ascertainable. ${ }^{7+}$ But the disparate impact of a cost-based reduction-in-force may still be attributable at least in part to age as a nonfortuitous element.

In light of the frequency with which American employers in both union and nonunion contexts provide higher rates of pay over years of accumulated service, ${ }^{75}$ older workers may indeed cost more to retain than younger employees in the same or comparable job categories. ${ }^{76}$

73. See pp. 581-83 infra (rejecting legitimacy of direct cost arguments). Reliance on detailed comparative performance ratings may lead to responsible personnel evalua. tion, but there are clear opportunities for deception.

74. An employer's ability to demonstrate that an individual older worker costs more distinguishes that factual situation from the circumstances of City of Los Angeles, Dep't of Water \& Power v. Manhart, 435 U.S. 702 (1978). In Manhart, the Court held that sex-based generalizations, derived from separate mortality tables, violated Title VII's focus on fairness to individuals. $I d$. at 708-09.

75. Numerous studies have confirmed a strong correlation between job tenure and advancing age. See, e.g., Hamel, Job Tenure of American Workers, January 1963, 86 Monthly LAB. Rev. 1145 (1963); O'Boyle, Job Tenure: How it Relates to Race and Age, Monthly LAB. Rev., Sept. 1969, at 16, 17-18. An empirical relation has also been established between job tenure and wage or salary levels. See, e.g., 3 U.S. MANPowER Administration, Dep't of Labor, The Pre-Retirement Years: A Longitudinal Study of the Labor Market Experience of MEN 67-68 (1973) [hereinafter cited as Pre-Retirement Years]; Suzuki, Age, Seniority and Wages, 113 Int'c Lab. REv. 67, 70-75 (1976); cf. Cox, Time and Incentive Pay Practices in Urban Areas, Monthly LAB. Rev., Dec. 1971, at 53, 54 (by implication).

Personnel practices among nonunion as well as unionized employees reflect this influence of job tenure on salaries. See, e.g., $\$ 715$ Research Materials, supra note 36, at 55; Suzuki, supra, at 71 . The effect on private nonunion rates of pay is particularly relevant, as it is in this area that cost-related illegal discharge litigation under the ADEA has been almost exclusively focused. See, e.g., Marshall v. Arlene Knitwear, Inc., 454 F. Supp. 715 (E.D.N.Y. 1978) (clothing designer); Donnelly v. Exxon Research \& Eng'r Co., 12 Fair Empl. Prac. Cas. 417 (D.N.J. 1974), aff'd mem., 521 F.2d 1398 (3d Cir. 1975) (mid-level manager); notes $48 \& 49$ supra (settlements and pending case).

76. The rate at which earnings increase with longevity of service varies among occupational categories, but the increase is fairly regular in virtually every major occupational group. See Pre-Retirement Years, supra note 75 , at 67.68 (positive correlation strongest for white males among professional and clerical sales workers, smallest among managers; major exception is white craftsmen, probably explained by influence of highly paid building trades); Suzuki, supra note 75, at 74 (seniority raises almost automatic in administrative posts, less automatic for production jobs). 
The impact of seniority on salary level is in some measure a function not simply of time served but also of ability to perform the job. Employers adopting formal compensation policies may rely on either "length of service" or "merit" or a combination of both in determining the range of rates paid for a single job classification. ${ }^{77}$ Because the notion of merit itself encompasses the value attached by the employer to experience on the job, the full extent of the influence of job tenure on pay remains uncertain. ${ }^{78}$ But when the value placed on work experience is added to the avowed reliance on length of service it suggests frequent employer recourse to job tenure as a factor in salary level determinations.

When an employer's reliance on job tenure to determine salary levels is coupled with the established relationship between age and tenure, the results are predictable. Older workers with accumulated years of service are paid at higher rates than younger workers in the same or comparable job categories who have served a lesser number of years. If that same employer appeals to comparative salary and fringe benefit costs as a reason for making termination decisions, the natural and foreseeable consequences are age-related. The employer has established an ostensibly age-neutral rule that, other things being equal, the costlier workers must be terminated first. But when the rule is applied to the realities of the employer's labor relations practice, its effect falls heavily and predictably on older employees. ${ }^{79}$

An employer might attempt to justify the foreseeable disparate impact by comparing the productivity per dollar of two similarly situated

77. See Cox, supra note 75 , at 54 .

78. See, e.g., Suzuki, supra note 75 , at 73 (skill key factor in wage determination; work experience, along with educational and training qualifications, important constituent of worker's skill); cf. D. Belcher, Compensation Administration 217-20 (1974) (business organizations typically refer to merit pay ranges, unless automatic increases part of union contracts; in fact, most pay ranges in business organizations involve movement based on seniority).

79. See, e.g., Marshall v. Arlene Knitwear, Inc., 454 F. Supp. 715, 730 (E.D.N.Y. 1978) (decision not to rehire complainant not based on age or work performance, but rather " 'purely a matter of dollars and cents' " favoring two younger pecrs); Opening Brief for Plaintiff-Appellee at 18, Bank of Cal. v. Naton, No. 78-1059 (9th Cir., filed Jan. 11, 1978) (employer sought fixed dollar savings through layoffs affecting as few employees as possible; knew older employees generally better paid than younger ones); cf. Griggs v. Duke Power Co., 40I U.S. 424, 431 (1971) (Title VII prohibits unnecessary employment practices fair in form but discriminatory in operation).

The Supreme Court found an exception to the Griggs "disparate impact" rulc in International Bhd. of Teamsters v. United States, 431 U.S. 324, 349 (1977), with regard to bona fide seniority systems that perpetuate the effects of pre-Act discrimination. In Teamsters, the Court relied heavily on the legislative history concerning protection of seniority systems under $\$ 703(\mathrm{~h})$ of the 1964 Civil Rights Act, 42 U.S.C. $\$ 2000 \mathrm{e}-2(\mathrm{~h})$ (1970). See 431 U.S. at 350-54. No analogous history exists for the ADEA. See note 91 infra (congressional concern that seniority system or benefit plan permitting forced early retirement would undercut purpose of protecting employees based on ability, not agc). 
employees, and concluding that the decision to terminate one rather than the other was based on comparative ability. ${ }^{80} \mathrm{But}$ if the older, more senior worker's ability has declined below that of the younger, a performance evaluation independent of salary will confirm this and justify the termination. If, on the other hand, the two workers are of roughly equal competence, and their unequal salaries are even in part a reflection of differential length of service which in turn correlates closely with age, then the "productivity per dollar" analysis simply disguises age as a determining factor. ${ }^{81}$ Because in order to find an ADEA violation age need only have been one among several determining factors, a finding that the employer credits job tenure for salary purposes and then terminates on the basis of comparative retention costs would seem to establish a case of prohibited discrimination under the ADEA. ${ }^{82}$

Admittedly, there can be no verdict of age discrimination without a judicial finding that length of service, advanced age, and high rates of pay are related in a predictable, nonfortuitous fashion. When an employer claims to use a salary system based purely on merit, a few instances in which workers discharged for direct cost reasons also happen to be older workers with seniority do not conclusively establish the agerelatedness of higher salary levels. ${ }^{83}$ On the basis of these instances,

80. That argument, in essence, was accepted by the court in Donnelly v. Exxon Research \& Eng'r Cc., 12 Fair Empl. Prac. Cas. 417, $421-22$ (D.N.J. 1974), aff'd mem., 521 F.2d 1398 (3d Cir. 1975). The apparent implication of the opinion is that when age (through seniority) is the sole factor in a replacement a violation occurs, but that if ability becomes a factor the evaluation is legitimate. This misconstrues the threshold for finding an ADEA violation. See p. 568 supra.

81. See note 15 supra (citing cases discussing age as factor).

82. Such prohibited discrimination derives absolutely no support from the policies underlying the seniority principle itself. Because employees rely on seniority for job security, these cost-based discharges deny them the fruits of that seniority. Although union contracts prevent such terminations by specifying order of layoffs, employees without the protection of organized labor need the protection afforded by the ADEA. $C f$. note 7 supra (discussing recent ADEA focus on providing protection for existing employees).

For employers, cost-based discharges bear no apparent relation to the seniority principle's aims of encouraging employee morale and loyalty to the organization, or retaining presumptively valuable experienced workers. Employee loyalty and moralc do not depreciate over time or decay with age-if anything the reverse is true. See, e.g., Hunt \& Saul, The Relationship of Age, Tenure, and Job Satisfaction in Males and Females, 18 Acad. Management J. 690, 699 (1975) (age and tenure bear positive relationship to overall job satisfaction). See generally S. SLichter, J. HeAly \& E. Livernash, The Impact of Collective Bargaining on Management 104-15 (1960) (discussing central role of seniority in employment relationship).

83. A particular obstacle to establishing age-relatedness as an employer policy or practice is the limited availability of class actions under the ADEA. See 29 U.S.C. $\$ \S 216(\mathrm{~b})$, 626(b) (1970) (permitting class actions only if every party plaintiff consents in writing). Courts have interpreted this written-consent requirement as foreclosing the possibility of class actions under FED. R. CIv. P. 23. See, e.g., LaChapelle v. Owens-Illinois, Inc., 64 F.R.D. 96, 98.99 (N.D. Ga. 1974), aff'd, 513 F.2d 286 (5th Cir. 1975). 
however, a court might create a rebuttable presumption that age was a determining factor in the salary structure. ${ }^{84}$ An employer could rebut the presumption by persuading the trier of fact that despite the disparate impact of his salary-related discharge selections and the frequent connection between advanced age and high salary, his method of wage determination takes no account of length of service. But such situations should rarely arise. The data on age and work performance suggest little reason, other than credit for length of service, why older workers should earn the highest salaries. ${ }^{85}$ The claims of any employer who argues that his older workers earn more based on "productivity" or "efficiency" but who lacks evidence of an objective performancebased wage system should therefore be subject to careful judicial scrutiny.

The intractable problem of extricating the age factor from actual salary differentials between older and younger workers can be contrasted with the less difficult task of separating advancing age from accurate performance differentials between those same workers. When older workers are terminated following objective findings of their comparatively lower productivity or efficiency, the reductions in cost are "based on [the employees'] ability rather than age." 80 But terminations of older workers that are grounded in salary differentials will in all likelihood occur either without change in the employees' performance levels, or due to a combination of age-related and abilityrelated factors. ${ }^{87}$ Because objective findings that higher direct cost is unrelated to advancing age are in practice virtually unobtainable, the Act militates strongly against discharges based on such direct cost differentials. ${ }^{88}$

84. Courts frequently create rebuttable presumptions when proof of fact A suggests with sufficient probability the existence of another fact B. See generally McCormick, supra note $26, \$ 343$, at $806-07$. In this instance, fact $A$ is the frequent or regular occurrence of higher salaries paid to older workers, especially those with greater seniority and the inferred fact $B$ is the existence of a causal relationship between age and higher salaries. Proof of fact $A$ may require additional salary data beyond that which was obtained regarding the discharged workers.

85. See pp. 576-77 supra. The presumption of competence attached to seniority may be stronger in a nonumion context, in which the absence of formalized institutional protection makes survival of incompetent workers less likcly. See $\$ 715$ RESEARCH MATERIALS, supra note 36 , at 55. But the survival of a competent senior worker, and his consequent advantage in terms of experience, do not inevitably make his performance superior to that of a younger and less senior co-worker, although this superiority may be demonstrated in particular instances.

86. ADEA, $\$ 2(\mathrm{~b}), 29$ U.S.C. $\$ 621(\mathrm{~b})(1970)$; see note 72 supra. The difficulty lies in reaching such correct and objective determinations. See pp. 578-80 supra.

87. See pp. 582-83 supra.

88. Although the question of whether either direct or indirect costs can be isolated from age as a determining factor was not addressed by Congress, it follows from application of one of the Act's major purposes to the cost issue. See p. 568 supra. The differing answers to this question account in part for the divergent remedial approaches proposed in this Note. 
This analysis of direct cost has proceeded on the assumption that no specific congressional intention can be discerned. Yet there are expressions of Congress's position with respect to cost and other personnel decisions under the ADEA. Although the Act and its legislative history are silent regarding the effect of cost on an employer's choice between retention and discharge of older workers, ${ }^{80}$ they do indicate strong concern that age-related differentials in direct costs not become a barrier to the hiring of older persons. ${ }^{90}$

Moreover, the 1978 amendments to the "bona fide benefit plan" exception explicitly protect the employment security of older workers from involuntary early retirement on the basis of age. ${ }^{.1}$ Forced retirement can be justified by reasons other than age, but these reasons must not be influenced by the underlying age-related factor of entitlement to regular pension payments. ${ }^{92}$ An employer's attempt to cut cost based on the variable of pension-entitlement seems tied impermissibly to the age factor. ${ }^{93}$ Thus, under the Act, age-related cost differentials appear

89. Discussion of employer costs in the original legislative history focuses on costs involved in hiring new older workers. See, e.g., 1967 House Hearings, supra note 62, at 91 (remarks of William R. Hutton); id. at 405 (Rep. Pucinski).

90. The proviso attached to $\S 4(f)(2)$ of the ADEA, 29 U.S.C. $\S 623(f)(2)(1970)$ ("except that no such [bona fide] employee benefit plan shall excuse the failure to hire any individual"), was added to the original bill following warnings from Senators Javits and Smathers that employers might otherwise cite a statutory requirement to provide equal benefit levels to newly hired older employees as a reason for refusing to hire them. See Age Discrimination in Employment: Hearings on S. 830 \& S. 788 Before the Subcomm. on Labor of the Senate Comm. on Labor and Public Welfare, 90th Cong., 1st Sess. 27, 29-30 (1967) [hereinafter cited as 1967 Senate Hearings]; House REPORT 805, supra note 7, at 4. For a clarification of the provision's meaning, see 113 CoNG. REC. 31,254-55 (1967) (Sen. Javits) (man who would not have been employed but for this law need not receive benefits of bona fide plan); ADEA Interpretations, 29 C.F.R. $\$ 860.120$ (a) (1977) (officially construed to allow unequal benefits). The exception evidences a tolerance for employers who wish to mitigate the cost burden created by addition of older workers, but at the same time it disapproves employer reliance on comparative fringe benefit costs as a basis for refusals to hire.

91. See 29 U.S.C. $\$ 623(f)(2)$ (1970), as amended by Act of Apr. 6, 1978, Pub. L. No. 95-256, $\S 2,92$ Stat. 189. The amendment reflects persistent congressional concern that any approval of age-based involuntary early retirement, even on a comfortable pension, will effectively subvert the Act's purpose of protecting employment based on ability and not age. See S. Rr. No. 493, 95th Cong., 1st Sess. 9, 10 (1977) (raising Act's upper age limit would be "empty gesture" if employees remained subject to involuntary early retirement provisions; "congressional action to clarify our original intent" made necessary by intervening conflicting judicial interpretations) [hereinafter cited as SENATE REPORT 493]; H.R. REP. No. 527, 95̄th Cong., 1st Sess., pt. 1, at 8 (1977) (same).

92. It is interesting, though hardly conclusive, that in identifying possible reasons other than age that might legitimate involuntary early retirement, the Senate committee report mentions disability and poor performance, but not cost. See SENATE REPORT 493, supra note 91 , at 10 .

93. Employers have on occasion advanced direct cost as a justification for implementing age-based forced retirements. Both courts and the enforcing agency have held that such involuntary retirements violate the ADEA. See Hannon v. Chrysler Motors Corp., 443 F. Supp. 802, 804-05 (E.D. Mich. 1978) (reduction-in-force called for laying off some employees ineligible for early retirement and compelling those age 55 or over to accept early retirement; held $\S 4(f)(2)$ exemption not applicable); Hays v. Republic Steel Corp., 12 Fair 
to excuse neither a refusal to hire older workers nor a willingness to retire them. There is no reason to assume that employer readiness to terminate older employees on a comparative direct cost basis should be treated differently. ${ }^{94}$

But if reliance on direct costs is predictably discriminatory in effect, it does respond to the employer's economic concerns. ${ }^{95}$ The ADEA was not intended to force employers to cease operations or absorb overwhelming economic losses, and Congress has elsewhere exhibited sen-

Empl. Prac. Cas. 1640, 1650 (N.D. Ala. 1974), aff'd in part and rev'd in part on ather grounds, 531 F.2d 1307 (5th Cir. 1976) (pension entitlement "one of the determining factors" in plaintiff's dismissal occasioned by adverse business circumstances; held clear case of age discrimination); Op. Wage \& Hour Adm'r 424 (U.S. Dep't of Labor Aug. 5, 1977), reprinted in 2 EMPL. PRAC. GuIDE (CCH) $\$ 5037$ (local government code provides for reduction of police and fire departments in economic hard times commencing with involuntary early retirement of oldest eligible employees; not justified under any ADEA exception); Op. Wage \& Hour Adm'r 302 (U.S. Dep't of Labor Apr. 24, 1975), summarized in I Empe. Prac. Guide (CCH) 1165.65 (state law reads "if for reasons of economy there is a reduction in Fire Department personnel, the men oldest in age and service shall be placed on pension" "; not justified under any ADEA exception).

None of these opinions considers whether the employer's cost explanation is simply that older workers cost less on retirement than on the payroll, or additionally that it costs less to terminate an older employee whose pension benefits are about to vest or to increase sharply, as opposed to an employee whose rights will not vest for many years. See generally Mastie v. Great Lakes Steel Corp., 424 F. Supp. 1299, 1317-18 (E.D. Mich. 1976) (dictum). Under the 1978 Amendments prohibiting all age-based involuntary retirement, neither cost explanation would survive review.

94. It is possible to argue, based on the statutory maxim expressio unius est exclusio alterius, that Congress's failure to address the issue of cost-based discharge when it dealt with pension costs and the refusal to hire is evidence that it viewed such discharges as permissible. There are several reasons to reject an application of the expressio unius maxim to this situation. Congress's failure in 1967 to address costs associated with the choice between discharge and retention is not at all surprising given the Act's original emphasis on promotion of hiring. See, e.g., 1967 Senate Hearings, supra note 90, at 52 (remarks of Sec'y of Labor) (collective bargaining agreements expected to provide adequately for older current employees, ADEA necessary for older job applicants).

In addition, Congress has rejected a judicial reading of the ADEA's substantive prohibition language that construed silence to mean exclusion from protection. Under the 1978 amendment to $\S 4(\xi)(2), 29$ U.S.C. $\$ 623(f)(2)(1970)$, Congress made clear that its previous failure to prohibit expressly all involuntary carly retirement based on age was never meant to suggest that the $\$ 4(f)(2)$ exemption permitted such retirement. See note 91 supra (citing relevant legislative history).

Finally, the general legislative purpose of the ADEA suggests that when Congress determines age-based forced retirement on an adequate pension to be unacceptable, a flat discharge on the same grounds will be no less so. Zinger v. Blanchette, 549 F.2d 901, 905 (3d Cir. 1977), cert. denied, 434 U.S. 1008 (1978) (distinguishing between "obviously undesirable" age-related discharge and involuntary retirement on adequate pension; latter excused under $\$ 623(f)(2)$ ); see United Air Lines v. McMann, 434 U.S. 192, 207-08 (1977) (White, $J$., concurring in judgment) (relying on Zinger). In disagrecing with the Zinger exemption of forced retirement on an adequate pension, Congress gave no indication that it saw age-related discharge as anything other than "obviously undesirable." See SENATE RePORT 493, supra note 91, at 10.

95. In this respect, it is distinguishable from a discriminatory reliance on indirect costs. See p. 580 \& note 72 supra. 
sitivity to employer personnel cost problems. ${ }^{96}$ The protection from discrimination afforded to competent older workers under the Act must at some point be balanced against an employer's possibly valid claim of business necessity.

\section{A Standard for Review of Cost-Based Discharges}

The less-detrimental-alternative standard, as developed in Title VII caselaw, ${ }^{07}$ encourages a search for alternatives to the challenged personnel practice that can accomplish the employer's business purpose with less harmful effects on the protected group. The standard assumes that at some point an employer's business purpose may become sufficiently compelling to override a predictable disparate impact on the protected group. This standard is well-suited to the current dilemma under the ADEA. When the practice challenged is termination of one or more competent older employees, a decrease in the number of workers discharged is one obvious indicator of a "less detrimental" result. ${ }^{98}$ In addition, when the business purpose is cost reduction, a court can compare different alternatives as means to this end. ${ }^{99}$

The less-detrimental-alternative standard typically would come into play in the following situation: for reasons of austerity, the employer has terminated workers ${ }^{\mathbf{1 0 0}}$ within a job category or classification who would be more costly to retain than other equally competent workers within the same category; and the discharged ADEA complainants have

96. See note 90 supra (discussing cost savings in hiring of older workers).

97. See, e.g., United States v. Bethlehem Steel Corp., 446 F.2d 652, 662 (2d Cir. 1971); Robinson v. Lorillard Corp., 444 F.2d 791, 798 (4th Cir.), cert. dismissed, 404 U.S. 1006 (1971). See generally Note, Business Necessity Under Title VII of the Civil Rights Act of 1964: A No-Alternative Approach, 84 YALE L.J. 98 (1974). Courts have not adopted the standard under the ADEA; moreover, its Title VII application has focused on hiring and promotion practices, not on discharge. But cf. Gill v. Union Carbide Corp., 368 F. Supp. 364, 366-68 (E.D. Tenn. 1973) (citing with approval employer's attempts to reconcile needs of older workers with need for economically viable business); Drucker \& Moore, supra note 10 , at $42-43$ (commending employer's approach in Gill).

98. It is not, however, the only conceivable indicator. For example, one could aim to minimize the total income lost to older workers by concentrating discharges on those eligible to receive alternative benefits. Nevertheless, a focus on reducing the number of terminations is easily measured and also comports with the Act's goal of protecting employment.

99. Although cost computations may be complex and ambiguous, it is more plausible to consider assessing whether alternative $\mathbf{X}$ saves as much money as the challenged practice than it is to contemplate measuring whether alternative $\mathbf{Y}$ is as likely to promote safety or efficiency. Courts have insisted that the latter be attempted. See, e.g., Sagers v. Yellow Freight Sys., Inc., 529 F.2d 721, 730 n.18 (5th Cir. 1976) (seniority system restricting transfers of city drivers must foster safety and efficiency better than any reasonably available less discriminatory alternative, otherwise invalid under Title VII).

100. The workers are not unionized; this is consistent with prototypical illegal discharge actions brought under the ADEA. See note 75 supra. 
demonstrated a disparate impact that was predictable in light of previous length-of-service pay increases. ${ }^{101}$

\section{A. Employer's "Substantial Cost" Burden}

An employer should be required to prove the magnitude of his economic problems before a court in effect consents to overlook the fact that age made a difference in the implementation of his austerity program. ${ }^{102}$ Because a predictably disparate impact is only tolerated as a result of an employer's economic self-interest, the deference traditionally accorded to an avowal of that self-interest is not appropriate. To maintain such deference would tacitly encourage employers to act on business motivations that are clearly discriminatory. ${ }^{103}$

In addition, the discriminatory impact being challenged is not strictly "job-related" as that term has been understood in an employment discrimination context. ${ }^{104}$ What is at stake is not a performancerelated occupational qualification but rather a purely economic consideration. ${ }^{105}$ When a showing of economic need is the sole explanation

101. Although this Note applies the less-detrimental-alternative standard to situations involving direct cost differentials, it might also be applicable in an indirect cost context when certain workers who happen to be older have been correctly assessed as marginally less competent than their colleagues. These workers would not be discharged but for the economic emergency, and the Act's goal of promoting job security among competent older workers suggests at least encouraging employers to consider less drastic means of cutting costs. Cf. note 131 infra (citing judicial encouragement of employer assistance to reductionin-force victims looking for new jobs). But unlike the salary-related differential, age is not a foreseeable determining factor in discharges based on indirect cost. See p. 584 \& note 72 supra.

102. By accepting the predictably disparate impact, a court is ignoring the heavier evidentiary burden ordinarily associated with nondiscriminatory implementation. See p. 572 supra.

103. See, e.g., Bishop v. Jelleff Assocs., 398 F. Supp. 579, 590 (D.D.C. 1974) (citing business purpose to appeal to younger clientele through younger employees). The normal advantages of control over access to relevant economic evidence (e.g., ability to interpret and if necessary manipulate that evidence) are magnified when producing data to support "economic purpose" is no Ionger simply a prelude to a showing of nondiscriminatory implementation. See p. 571 supra.

104. The "business necessity" doctrine in Title VII actions requires that an employment practice producing disparate impact on a protected group be shown to be "related to job performance." Griggs v. Duke Power Co., 401 U.S. 424, 431 (1971). Employer claims of job-relatedness under Title VII have involved efforts to show that the challenged practice is an indicator of who will perform effectively on the job. See, e.g., Dothard v. Rawlinson, 433 U.S. 321 (1977) (minimum height and weight requirements for position of prison guard); Albemarle Paper Co. v. Moody, 422 U.S. 405 (1975) (general ability tests applied to all applicants for skilled labor).

105. Judicial review of occupational qualifications (BFOQ) under the ADEA is confined to examining the relationship between age and a performance-related business objective. See note 24 supra. There are indications that BFOQ analysis includes tacit recognition of cost as an element, although certainly not, as here, the only element. See, e.g., Hodgson v. Greyhound Lines, Inc., 499 F.2d 859 (7th Cir. 1974), cert. denied, 419 U.S. 1122 (1975) (refusal to hire older bus drivers sustained as safety BFOQ; court approved by implication 
for a certain discriminatory effect, the employer should have a threshold burden of persuading the trier of fact as to the substantiality of that need.

Employers in other contexts have been required to demonstrate a "substantial and legitimate"10s business purpose, or one that is "sufficiently compelling," 107 in order to justify allegedly neutral business practices that conflict with employees' statutorily protected rights. The diversity of business structures and economic circumstances among employers argues against any single definition of what constitutes a substantial or compelling cost problem. ${ }^{108}$ But to override a finding of disparate impact, an employer must show more than simply a need to maximize profits or to streamline operations. An employer might meet his "substantial cost" burden by demonstrating that unless costs are cut sharply his firm's business reputation will be endangered. ${ }^{109} \mathrm{Al}$ ternatively he may be able to justify significant cost reductions by demonstrating his company's imminent insolvency, ${ }^{110}$ or by appealing

employer unwillingness to defray costs of individual screenings, or of more protective personnel structure). Implicit judicial respect for the employer's cost discretion in some BFOQ hire cases has not extended to BFOQ discharge cases, perhaps because the "cost" of individualized testing is made practicable by access to performance and physical capacity records of current employees. See, e.g., Houghton v. McDonnell Douglas Corp., 553 F.2d 561 (8th Cir.), cert. denied, 494 U.S. 966 (1977); Aaron v. Davis, 414 F. Supp. 453 (E.D. Ark. 1976).

106. NLRB v. Brown, 380 U.S. 278, 289 (1965) (lockout and hiring of temporary replacements serves substantial and legitimate business end); see NLRB v. Great Dane Trailers, Inc., 388 U.S. 26, 34 (1967) (no evidence of legitimate and substantial business justification for decision to deny vacation pay to strikers).

107. Robinson v. Lorillard Corp., 444 F.2d 791, 798 (4th Cir.), cert. dismissed, 404 U.S. 1006 (1971) (department seniority system lacks sufficiently compelling business purpose to override racial impact); see Head v. Timken Roller Bearing Co., 486 F.2d 870, 879 (6th Cir. 1973) (requiring review to determine presence of sufficiently compelling business purpose). For a requirement that firms prove compelling economic purpose in another area of substantive law, see P. AreedA, Antrtrust Analysis 739-46 (2d ed. 1974) (discussing failing company doctrine as defense to mergers challenged under antitrust laws).

108. Courts requiring a substantial business purpose in reviewing unfair labor practice claims have addressed the problem of substantiality on an individual employer basis. See, e.5., Inter.Collegiate Press, Graphic Arts Div. v. NLRB, 486 F.2d 837, 840-43 (8th Cir. 1973), cert. denied, 416 U.S. 938 (1974). In evaluating the Title VII "business necessity" defense, courts also have responded case by case, but with little indication of what qualifies as a "sufficiently compelling" business purpose. See, e.g., Robinson v. Lorillard Corp., 444 F.2d 791, 798.99 (4th Cir.), cert. dismissed, 404 U.S. 1006 (1971).

109. This approach has been permitted in labor relations litigation. See, e.g., NLRB v. Brown, 380 U.S. 278, 284 (1965) (temporary replacements justified, retail food industry); Inter-Collegiate Press, Graphic Arts Div. v. NLRB, 486 F.2d 837, 842 (8th Cir. 1973), cert. denied, 416 U.S. 938 (1974) (temporary replacements justified, printer's busy season).

110. Courts have upheld a similar "failing company" defense in antitrust litigation. See, e.g., Union Leader Corp. v. Newspapers of New Eng., Inc., 284 F.2d 582, 587 (Ist Cir. 1960), cert. denied, 365 U.S. 833 (1961); United States v. Maryland \& Va. Milk Producers Ass'n, 167 F. Supp. 799, 808 (D.D.C. 1958), aff'd, 362 U.S. 458 (1960). 
to the recurrent operating losses of a particular division ${ }^{111}$ or to the cutback or elimination of a major funding source.112

\section{B. Plaintiff's "Reasonable Alternatives" Burden}

The ADEA endorses efforts to devise workable remedies that minimize the discriminatory impact of employment practices. ${ }^{13}$ Once an employer has established a substantial cost problem to which a reduction in personnel certainly bears a reasonable relation, the question becomes whether discharge of costlier employees is an unavoidable response to the problem. ${ }^{114}$ Requiring the employer himself to provide an answer would yield a limited range of alternative responses, ${ }^{115}$ and also pose the significant problem of negative proof. ${ }^{116}$ Encouraging a court to propose particular alternatives would involve the judiciary directly in making complex and far-reaching business judgments that may be considerably beyond its competence. ${ }^{117}$ The plaintiff, as the

111. See, e.g., Marshall v. Roberts Dairy Co., 15 Fair Empl. Prac. Cas. 633, 636-37 (D. Neb. 1977), aff'd, 572 F.2d 1271 (8th Cir. 1978) (company's retail operations lost money for number of years, then eliminated); Schulz v. Hickok Mfg. Co., 358 F. Supp. 1208, 1211 (N.D. Ga. 1973) (company lost money for five consecutive years).

112. See, e.g., Gill v. Union Carbide Corp., 368 F. Supp. 364, 366 (E.D. Tenn. 1973) (employer dependent on contractual arrangement with Atomic Energy Commission; budget reduction results from decreased level of AEC funding).

113. See ADEA, $\$ 2(\mathrm{~b}), 29$ U.S.C. $\$ 621$ (b) (1970) (one purpose of Act "to help employers and workers find ways of meeting problems arising from the impact of age on employment"); id. $\$ 7(\mathrm{~b}), 29$ U.S.C. $\$ 626$ (b) (1970) (courts have jurisdiction to grant whatever equitable relief is deemed appropriate to effectuate such purpose). Courts have been slow to devise or encourage such alternative relief in comparison with remedial approaches undertaken by courts applying Title VII. See, e.g., Williams v. Boorstin, 451 F. Supp. 1117 (D.D.C. 1978); United States v. Ironworkers Local 86, 315 F. Supp. 1202 (W.D. Wash. 1970), aff'd, 443 F.2d 544 (9th Cir. 1971), cert. denied, 404 U.S. 984 (1971).

114. Under the Title VII business necessity doctrine, the challenged employment practice "must be shown to be necessary to safe and efficient job performance." Dothard v. Rawlinson, 433 U.S. 321, 332 n.14 (1977); see Griggs v. Duke Power Co., 401 U.S. 424, 431 (1971). An exclusionary employment practice would not appear to be necessary if it can be shown that some less exclusionary employment practice accomplishes the same objectives. See Note, supra note 97, at 113 n.66. At least one court has discussed "business necessity" analysis in an ADEA illegal discharge action. See Mistretta v. Sandia Corp., 15 Fair Empl. Prac. Cas. I690, I710 (D.N.M. 1977).

115. The employer is not likely to have an interest in persuading a court that there are less detrimental alternatives available; if he did he probably would have initiated them.

116. Cf. Developments in the Law-Employment Discrimination and Title VII of the Civil Rights Act of 1964, 84 HARv. L. REv. 1109, 1130 (1971) (impractical for employer to demonstrate that no less detrimental alternatives are available).

117. Cf. Furnco Constr. Corp. v. Waters, 98 S. Ct. 2943, 2950 (1978) (purpose of Title VII does not support court requiring business to adopt what court perceives to be "best" hiring procedures; courts should not attempt to restructure business practices when not mandated to do so by Congress). But even if judicially developed proposals are inappropriate, the experience of Title VII administrators, judicially appointed to implement and in some instances to give meaning to far-reaching remedies decrced by courts, may offer a useful model for cases under the ADEA. See generally Harris, The Tille III Administrator: A Case Study in Judicial Flexibility, 60 CoRnell L. Rev. 53 (1974). 
party whose interest lies in alternatives to discharge, is in the best position to present a wide range of alternatives. ${ }^{118}$

At the same time, in order to protect employers from the harassment of interminable frivolous proposals, the plaintiff's burden should be to present only reasonable alternatives. ${ }^{119}$ A fair amount of specificity will be demanded of employers in determining the substantiality of economic need, and a plaintiff should have to set forth a comparably detailed alternative proposal. ${ }^{120}$ There is a limited range of reasonable alternatives to a reduction-in-force, ${ }^{121}$ and a private plaintiff need not rely solely on creative imagination to suggest how they might be applied, individually or in combination, to the evidence before him..$^{122}$

One alternative that might produce an abatement of costs comparable to that achieved through a reduction-in-force ${ }^{123}$ is a compre-

118. See Note, supra note 97, at 114 n.68; cf. United States v. Bethlehem Steel Corp., 446 F.2d 652, 666 (2d Cir. 1971) (court rules on alternatives to discriminatory transfer system urged on court by plaintiff).

119. Alternatives are "reasonable" if they respond both to the older employees' right to avoid termination and to the employer's need to cut costs. Although employees outside the protected group may have interests in opposition to those of older discharged workers, the younger employees lack a statutory basis under the ADEA for presenting their interests to a court. The Act's aim to protect a limited class rather than to assure an age-neutral approach for all employees is distinguishable from Title VII. See Weber v. Kaiser Aluminum \& Chem. Corp., 563 F.2d 216 (5th Cir. 1977), rehearing denied, 571 F.2d 337 (5th Cir. 1978) (white employee successfully challenges affirmative action training plan under Title VII). Those enforcing the ADEA have voiced approval of favored treatment for older workers. See, e.g., Op. Wage \& Hour Adm'r 419 (U.S. Dep't of Labor July 1, 1977), reprinted in 2 EMPL. Prac. GuIDE (CCH) 5036 (approves employer practice of excusing older workers from compulsory rotation into undesirable jobs); Op. Wage \& Hour Adm'r 404 (U.S. Dep't of Labor Aug. 26, 1976), reprinted in 2 EMPL. Prac. Gulde $(\mathrm{CCH}) 5023$ (approves collective bargaining agreement providing that at least $20 \%$ of journeymen be 55 years of age or older). Given the nature of statutory protection, the interests of younger employees would have to be heard-if at all-in the conciliation stage preceding initiation of a lawsuit.

120. If, on the other hand, an employer's largely undocumented claim of a substantial cost problem is accepted by a court, the threshold for reasonableness should be lowered. The extent of detail available will incvitably be tied to plaintiff's knowledge of the employer's economic needs and business structure, which is in turn a function of the employer's initial presentation or plaintiff's related discovery. Cf. Cooper \& Sobol, Seniorily and Testing Under Fair Employment Laws: $A$ General Approach to Objective Criteria of Hiring and Promotion, 82 HARv. L. REv. 1598, 1669 (1969) (Title VII plaintiffs' burden flexible, tailored to level of detail in employer's original presentation); Note, supra note 97, at 114 (same).

121. See, e.g., Hershficld, Reducing Personnel Costs During Recession: Are There .1lematives to the Layoff? CoNF. BD. REc., June 1975, at 21-22 (methods of personnel cost reduction include attrition, fewer hours of work per week, alternating periods of work, postponed pay increases, cuts in pay and benefits, encouraging (not requiring) early retirement, temporary layoffs, permanent separations).

122. The Solicitor's Office in the Department of Labor brings a number of actions alleging discriminatory reductions-in-force, and could serve as a resource facility in developing alternative strategies for meeting employer's serious economic problems.

123. Natural events (e.g., attrition of work force) or voluntary individual actions (e.g., taking early retirement as requested or encouraged by employer) are not likely to respond adequately to the economic urgency of the situation. They may, however, be an important supplement when a plaintiff proposes that the employer use a combination of approaches. 
hensive adjustment in the salary structure. The plaintiff might propose a reappraisal of job categories based on what each category is actually worth, with pay rates adjusted to reflect a single level or narrow range of compensation for each classification. Such a scheme would affect disproportionately those with the longest service, but it would preserve employment security. ${ }^{124}$ Pay rates might also be reduced across the board so that the wages of all employees in the relevant unit or division would be scaled down. ${ }^{125}$

When pay rate reductions are inappropriate, ${ }^{126}$ one or more other alternatives may be more suitable. Work sharing, achieved through either a reduced work week or alternating periods of work, ${ }^{127}$ may

124. Wages would be reduced more for older than for younger workers; but the scheme constitutes a less detrimental alternative than discharge, for it would at most undo the advantages previously associated with seniority. The "worth" of a given job category would reflect what an employer presently could afford to pay, presumably using the lower end of the pay range as a baseline because the employer himself initially concluded that the job was "worth" at least that much. Although the emplojer could in theory propose that the job is now worth even less than the former minimum, he may be discouraged from doing so in order not to drive away virtually all his employees or thoroughly destroy employee morale. See note 126 infra.

125. Cf. 227 DAILY LAB. REP. (BNA) A3-4 (Nov. 22, 1974) (Wage and Hour Administrator announces approval of plant-wide wage reduction requested by employer as alternative to layoffs; union agreed to reduction).

Unilateral pay reductions (as opposed to job redefinitions) face the obstacle of $\$ 4(a)(3)$ of the Act, 29 U.S.C. $\$ 623(a)(3)(1970)$, which makes it unlawful for an employer "to reduce the wage rate of any employee in order to comply with this chapter." But the language is less conclusive than it seems on its face. The prohibition of $\$ 4(a)(3)$ is derived in haec verba from a section of the Equal Pay Act, 29 U.S.C. $\$ 206$ (d)(1) (1970), intended primarily to prevent employers from reducing male wages to remedy an illegal wage rate differential between males and females. See, e.g., 109 CoNG. REc. 9211-12 (1963) (Rep. Ryan) (Act aimed at redressing inequalities borne by women); H.R. REP. No. 309, 88th Cong., lst Sess. 2, reprinted in [1963] U.S. Code CoNg. \& AD. News 687, 688 (lower wage rate must be increased to level of higher). The Department of Labor, which submitted the original bill to Congress, perceived $\S 4(\mathrm{a})(3)$ to have the limited meaning associated with 29 U.S.C. $\$ 206$ (d)(1). See ADEA Interpretations, 29 C.F.R. $\$ 860.75$ (1977); Note, supra note 10, at 399; Telephone Interview with Paul Brenner, attorney in Wage \& Hour Div., U.S. Dep't of Labor (Aug. 24, 1978) (referring to 1967 memorandum from Legislative Division, Solicitor's Office, U.S. Dep't of Labor, to Sen. Comm. on Labor and Public Welfare) (notes on file with Yale Law Journal).

The reduction proposed here is not in response to an existing illegal differential, nor does it involve reducing wages only of those outside the protected class. In addition, this pay reduction represents a less detrimental alternative remedy proposed by plaintiffs, not an effort by the employer to avoid liability under the Act. Literal enforcement of $\$ 4(a)(3)$ would in effect encourage termination of higher paid older workers, a result hardly consonant with the Act's remedial purposes.

126. Reducing salaries may threaten employee loyalty or morale, and in practice it is infrequently initiated by employers. See, e.g., Hershfield, supra note 121, at 21 (only three to six percent of firms surveyed resorted to cuts in pay and benefits to reduce costs).

127. See U.S. Bureau of Labor Statistics, Dep't of Labor, Bull. No. 1425-13, LayofF, Recalt and Work-Sharing Procedures 3 (1972) (survey reported approximately 25\% of collective bargaining agreements, covering $36 \%$ of work force, contained provisions for work sharing); Summers \& Love, Work Sharing as an Alternative to Layoffs By Seniorily: Tille VII Remedies in Recession, 124 U. PA. L. REV. 893, 926-34 (1976) (work sharing as tradition within American industry). For an example of work sharing initiated by em- 
yield substantial cost savings. The right to displace or "bump" a less senior worker, based on seniority within one or several closely related job categories, would reduce cost with minimal disruption of operations, and would also be easy to administer. ${ }^{128} \mathrm{~A}$ shift to incentive pay practices would control future costs by tying individual pay rates closely to actual production. ${ }^{129}$ There is also the option of requiring employers to offer discharged employees other jobs within the organization as these become available, ${ }^{130}$ or to provide meaningful assistance in their search for jobs elsewhere. ${ }^{131}$

\section{Employer's Burden to Reject Less Detrimental Alternatives}

If the plaintiff advances alternatives with a less detrimental impact, the employer must demonstrate that such alternatives would be inadequate from a cost perspective. ${ }^{132}$ In particular, an employer will

ployees, see Flint, Sandhogs Share the Digging and Dig the Sharing, N.Y. Times, June 16,1978 , at B-1, col. 5 (thrce locals in operating engineers union voted to cut work shifts from eight to six hours in order to retain 100 additional workers).

128. When bumping rights are limited by job category, the senior worker ideally can bump only into jobs he used to perform himself, or into the job he now performs. See generally S. SLichter, J. Healy \& E. LiverN.ssh, supra note 82, at 158-68 (bumping and its limitations in unionized setting). However, bumping threatens the job security of employees most recently hired, and may adversely affect an employer's efforts to provide job opportunitics for other protected groups, notably women and racial minorities. For this reason, other approaches may be preferred.

129. Incentive methods of pay include piece-rate, production bonus, and commission systems. They are more often applied to industrial plant workers than to office workers, for whom few jobs have quantifiable performance criteria. See Cox, supra note 75, at 54; Suzuki, supra note 75 , at 73-74.

130. Cf. Arnold Graphics Indus., Inc. v. NLRB, 505 F.2d 257, 260 (6th Cir. 1974) (enforcement of Labor Board order of reinstatement; laid-off employees for whom jobs not available given preferential consideration for job openings in other plants); Darlington Mfg. Co. v. NLRB, 397 F.2d 760, 773 (4th Cir. 1968), cert. denied, 393 U.S. 1023 (1969) (same); Dyment, Softening the Blow of Temporary Layoffs, PENsion Wordd, Aug. 1976, at $64-65,68$ (company receives government funds for "learning on layoff" program; laidoff employees given technical training, are more efficient when recalled).

131. Although the Act does not expressly impose a duty on employers to assist in locating other work for older employees terminated for austerity reasons, several courts have been favorably disposed toward defendants who have made such an effort, and unfavorably disposed toward those who have failed to do so. See, e.g., Gill v. Union Carbide Corp., 368 F. Supp. 364 (E.D. Tenn. 1973); Schulz v. Hickok Mfg. Co., 358 F. Supp. 1208 (N.D. Ga. 1973). At least one court of appeals has intimated that the defendant employer's obligation in this area remains an open question. See Surrisi r. Conwed Corp., 510 F.2d 1088, 1090 (8th Cir. 1975) (dictum). But see Donnelly v. Exxon Research \& Eng'r Co., 12 Fair Empl. Prac. Cas. 417, 422 (D.N.J. 1974), aff'd mem., 521 F.2d 1398 (3d Cir. 1975) (dictum) (law does not yet require employer to find commensurate work for employee elsewhere).

132. Although courts have not required such a demonstration under the ADEA, they have done so under Title VII. See, e.g., Robinson v. Lorillard Corp., 444 F.2d 791, 798 (4th Cir.). cert. dismissed, $40 \div$ U.S. 1006 (1971) (must be no acceptable alternative policies that would better accomplish compelling business purpose, or accomplish it equally well with lesser differential racial impact). But cf. Smith v. Olin Chem. Corp., 555 F.2d 1283, 1288 (5th Cir. 1977) (job criterion so manifestly job-related that court recognizes business necessity per sc, with no evidentiary burden placed on employer). 
have to show not simply that the less discriminatory alternative, which may well involve a more pervasive disruption of the status quo, ${ }^{133}$ costs more to implement, ${ }^{134}$ but that the cost differential is a substantial one. ${ }^{135}$ In light of the expressed congressional opposition to citing cost as a reason for not hiring older workers, ${ }^{136} \mathrm{a}$ less than substantial cost should not excuse a failure to retain them.

The burden of rejecting less detrimental alternatives is not, however, insurmountable. If the employer has already considered costreducing options that are less severe than job termination, he should be able to make the necessary showing in rebuttal. Application of a less-detrimental-alternative standard will encourage such foresight, and may diminish the likelihood of initial resort to personnel reductions having a disparate impact-reductions that often become the subject of costly litigation. This outcome would be consistent with the statutory preference for conciliation and persuasion rather than court action. ${ }^{137}$ Employers would be further encouraged to conciliate by the prospect of losing all influence over the remedial process should the court approve one of the plaintiff's proffered less detrimental alternatives. Yet even if an employer goes to trial without having previously

There is the possibility that initially feasible alternatives will have become inadequate or obsolete by the time the parties reach court. If an employer failed to pursue less detrimental alternatives that were available, and no such alternatives are now available, he should be assessed damages under the Act. This possibility highlights the need for rapid judicial consideration of such discharge cases. See p. 595 infra.

133. Both widespread salary reductions and work sharing by definition affect more employees directly than do selected terminations.

134. Cost, in this context, is measurable in terms of efficiency as well as dollars. Thus if deteriorating employee morale caused by pay reductions adversely affects overall productivity, it is a relevant cost factor-provided it is proven rather than merely asserted.

135. Courts have assigned different cost burdens to employers under Title VII, depending on the nature of the discrimination. Compare Trans World Airlines $v$. Hardison, 432 U.S. 63, 84 (1977) (termination justified when accommodation to single employee's Saturday religious observance not possible without "undue hardship"; relatively low-cost hardship accepted by Court without detailed employer demonstration) with Jones $v$. Lee Way Motor Freight, Inc., 431 F.2d 245, 250 (10th Cir. 1970), cert. denied, 401 U.S. 954 (1971) (employers can justify disparate racial impact based on cost only if additional costs of less discriminatory practice substantial). Hardison is distinguishable from the instant factual situation. The employer charged with age discrimination in his reduction-in-force has actively initiated a practice that adversely affects the protected class. This is morc closely analogous to the initiation of a practice with a racially or sexually disproportionate impact than to the failure to respond to a special request in Hardison. In addition, $\$ 701$ (j), 42 U.S.C. $\$ 2000 \mathrm{e}(j)$ (Supp. V 1975), which excuses an employer when he can demonstrate "unduc hardship," is by its terms applicable only to religious discrimination. Finally, the Supreme Court in Hardison concluded that bearing any more than de minimis cost to favor a member of one religious group but not others would violate the equal treatment provision of Title VII. 432 U.S. at 84-85. But equal treatment requirements are not dispositive under the ADEA, which aims to protect a limited class. Sce note 119 supra.

136. See p. 585 supra.

137. See ADEA, § $7(\mathrm{~d}), 29$ U.S.C. $\$ 626(\mathrm{~d})(1970)$. 
explored other methods of substantially reducing cost, the limited number of practicable options suggests that his burden in court will not be excessive.

\section{Need for Speed}

In balancing the conflicting interests of an employer seeking a reduction-in-force and older employees challenging termination, a court must act quickly. Lengthy litigation results in an extended period of enforced idleness for those discharged. Although illegally terminated employees ultimately are "made whole" in monetary terms, back pay cannot compensate for the consequences to an older worker's physical health and mental welfare often associated with forced inactivity. ${ }^{138}$ When resolution is delayed until close to retirement age, the loss is even more likely to be irreparable. The presumably continuing competence of those adversely affected strengthens the argument for an equitable remedy that minimizes unnecessary loss of employment. ${ }^{139}$

\section{Conclusion}

The ADEA protects competent older workers from discriminatory employment decisions, however indirect or unintentional the discrimination. At some point, this protection must be balanced against an employer's legitimate economic imperatives. The employer's desire to reduce his business costs will continue to receive judicial recognition under the ADEA. But even the most critical cost considerations need not be addressed through age-related categories. If courts will make clear that alternatives less detrimental than salary-related discharge are the preferred response under the ADEA, employers may elect to pursue a more conciliatory approach and may incidentally avoid the costs of litigation. Such a judicial emphasis should serve to strengthen the employment protection to which older workers are entitled under the Act.

138. See Committee on Aging, American Medical Association, Retirement-A Medical Philosophy \& Approach 2 (1972) ("There is ample clinical evidence that physical and emotional problems can be precipitated or exacerbated by denial of employment opportunities."); B. Kutner, D. Fanshel, A. Togo \& T. Langner, Five Hundred Over SixTY 253 (1956) (unless forcibly retired older person can find "productive, routinized, and ego-satisfying substitute for employment," he faces situation "as devastating to his self-image and social adjustment as would be a mandatory rule that he change sexes at a given age").

139. The time element frequently associated with a detailed presentation, such as is here required of both parties, can be minimized by judicial attention to the "substantial cost" threshold that alone can trigger judicial review, and to the limited number of reasonable alternatives available. 